\title{
19. X-RAY MINERALOGY STUDIES, DEEP SEA DRILLING PROJECT LEG 601
}

\author{
C. Latouche and N. Maillet, Institut de Géologie du Bassin d'Aquitaine (Laboratoire associé au CNRS No. 197) \\ Université de Bordeaux I, Bordeaux, France \\ and \\ R. Blanchet, Laboratoire d'Océanologie et Géodynamique, Université de Bretagne Occidentale, Brest, France
}

\begin{abstract}
A bulk-sediment and clay-fraction X-ray diffraction study of samples from Deep Sea Drilling Project Leg 60 shows an abundance of the following minerals: plagioclase feldspar, zeolite, smectite, Fe-Mg chlorite, attapulgite, and serpentine. Amorphous compounds are also abundant.

The variations in abundance of the different components correspond to episodes of volcanic activity through time. Deposits from periods of great activity are composed of sediments very rich in amorphous matter and in "primary" minerals (e.g., plagioclase feldspars). During relatively quiet periods, clay minerals and zeolites predominate.
\end{abstract}

\section{INTRODUCTION}

The present study deals with the mineral composition of sediments from the 10 sites (452-461) explored during Leg 60 . These sediments constitute a cross section of an active margin comprising an oceanic plate undergoing subduction, a trench, a trench arc complex, an insular arc, and an active marginal basin (Fig. 1). Basement was reached at Sites $453,454,456,458$, and 459 . The sedimentary series from the trench arc assemblage extends across the Tertiary and Quaternary periods (from upper Eocene to Recent); the marginal basin is restricted to the Pliocene-Quaternary period, which corresponds with the opening of the basin (Packham et al., this volume).

The sedimentary history of the Pacific Plate includes the period from Late Cretaceous to Recent as well as a very important hiatus ("the Great Hiatus of the western Pacific') in the stratigraphic interval between the Upper Cretaceous and various Cenozoic layers (Site 452 report, this volume).

A cross section through the Tertiary enables the major discontinuities to be plotted across the different sites, including various hiatuses determined with precision from Holes 458 and 459B, especially upper Miocene to lower Pliocene, and general tectonic discontinuities of the middle and upper Eocene.

In all, we studied 123 samples. They comprise all major sediment types identified aboard ship. Thus they permit us to define the general mineralogical characteristics of the deposits rather than focusing on one particular facies or period. More specialized work, using complementary sampling, was carried out in parallel to this study (Desprairie, this volume). Special attention was paid to Site 460 at the request of the scientific team because it was considered particularly important to the interpretation of the geodynamic history of the active margin.

\footnotetext{
${ }^{1}$ Intial Reports of the Deep Sea Drilling Project, Volume 60.
}

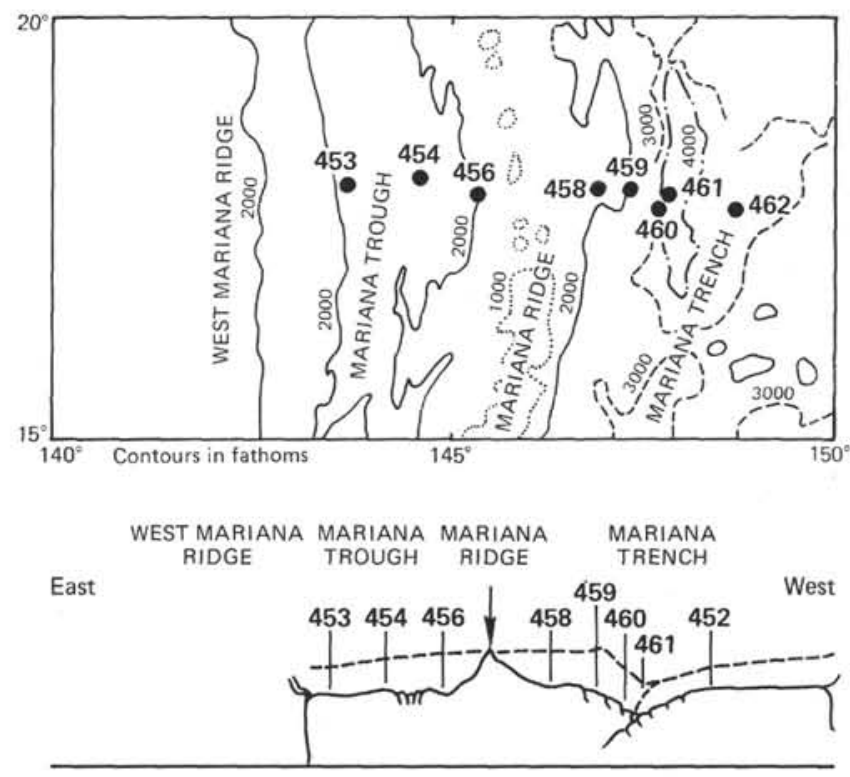

Figure 1. Location of Leg 60 drilling sites and active margin cross section.

The dominant lithological characteristic of the samples from all the sites is an abundance of volcanodetritic materials. In addition, the marginal basin sites (453-456) are highly siliceous and very poor in carbonates (less than 10\%). By contrast, in the zone between the arc and the trench (Holes 458 and 459B) carbonates are abundant.

\section{MINERALOGY}

The mineralogical analysis was performed by X-ray diffraction (see Appendix for methods), partly on untreated sediment (powder diffractograms) and partly on the $<2 \mu \mathrm{m}$ fraction clay (oriented paste). Complementary observations were undertaken on untreated sediment, using a scanning electron microscope (SEM); on the fine fraction $(<2 \mu \mathrm{m})$, using electronic transmis- 
sion microscope (TEM); and on glass discs using X-ray fluorescence for chemical analyses (Lapaquellerie, 1975).

In general, crystallized minerals are present only in small amounts by comparison to amorphous products, whose almost constant presence is shown by the considerable extent of "continuous background" between $5.60 \AA$ and $3.60 \AA$ on the X-ray diffractograms. This we attribute to the presence of amorphous silica (e.g., Trichet, 1970, and Greenwood, 1973) in volcanic ash and glass and/or siliceous organisms.

The principal minerals are the following:

Calcite is identified by its peak at $3.03 \mathrm{~A}$ and chemically with the aid of a calciometer. Although calcite is relatively scarce in Leg 60 sediments, some strata clearly do contain carbơnates (Holes 454A, 456, 456A, and 459B).

Quartz is recognized according to its characteristic peaks at $4.24 \AA$ and $3.35 \AA$; the relative intensity of these lines identifies two types of quartz and their origin (Eslinger et al., 1973): $4.24 \AA<3.35 \AA$ identifies derital quartz, whịch occurs frequently but in small quantities; $4.24 \AA->3.35 \AA$ identifies authigenic quartz, which occurs in some fine fractions $(<2 \mu \mathrm{m})$ in Holes 456 and $456 \mathrm{~A}$.

Silica is crystallized in the form of opal CT and is characterized by a broad peak between $4.13 \AA$ and 4.06 $\AA$ (Jones and Segnit, 1971; Griffin et al., 1972). The siliceous levels are located at the base of Holes 459B and 452A.

Feldspars are divided into two groups: K-feldspars, identiable by peaks between $3.26 \AA$ and $3.20 \AA$ and very rare (Holes 453 and $452 \mathrm{~A}$ ), and plagioclase feldspars, characterized by peaks between $3.19 \AA$ and 3.16 $\AA$, abundant in all the sites.

Zeolites are subdivided into three types, identified according to Deffeyes (1959), Robinson (1966), and Reynolds (1970): clinoptilolite/heulandite peaks at $9 \AA$; phillipsite lines are at 7.02 $\AA$ and $3.20-3.18 \AA$; analcime or wairakite peaks at $5.54,3.43$, and $2.95 \AA$.

Because these minerals are frequently better observed in the bulk sediment than in the fine fraction, their particle size seems to be relatively large. Each of these types appears to be restricted to a particular sedimentary episode. In the fraction of particles less than $2 \mu \mathrm{m}$ the following clay minerals occur:

Smectites are the most common clay minerals. More or less well crystallized, they sometimes display a slow swelling in glycol ethylene (Fan and Zemmels, 1972), a characteristic already recognized in the altered clays from volcanic material in the region of Rockall (Latouche and Maillet, 1979).

Chlorites occur, first, as particular chlorites, which show strong 001, 002 reflections and slight 003, 004. At $550^{\circ} \mathrm{C}$ the peak at $7 \AA$ loses intensity but continues, whereas the line at $14 \AA$ is always high. They seem to be related to the $\mathrm{Fe} \mathrm{Mg}$ chlorites described by Sudo and Shimoda (1978). For the purposes of this chapter these minerals thus will be designated "Fe Mg chlorites.", They occur abundantly in the Pleistocene sediments in Holes 456 and 456A, where they are frequently associated with irregular mixed layers of illite-smectite (I-M) or chlorite-smectite (C-M) types (Fig. 2, A and B). Examination of this mineralogical association by SEM and TEM reveals a facies of plates dissociated into laths (Plate 1, Figs. 1 and 2). The chemical analysis of this clay phase gives the following results:

\begin{tabular}{lcccccc}
$\begin{array}{c}\text { Sample } \\
\text { (interval in cm) }\end{array}$ & $\mathrm{SiO}_{2}$ & $\mathrm{Al}_{2} \mathrm{O}_{3}$ & $\mathrm{CaO}$ & $\mathrm{MgO}$ & $\mathrm{TiO}_{2}$ & $\mathrm{Fe}_{2} \mathrm{O}_{3}$ \\
\hline $456 \mathrm{~A}-9-3,17-19$ & 42.49 & 17.92 & 0.13 & 8.70 & 0.73 & 17.28 \\
\hline $456-14-1,88-89$ & 39.72 & 15.08 & 6.30 & 7.07 & 1.43 & 14.77 \\
\hline \multicolumn{7}{c}{$\begin{array}{c}\text { Loss by } \\
\text { Heating }\end{array}$} \\
\hline $465 \mathrm{~A}-9-3,17-19$ & 0.29 & 2.06 & 9.36 & & \\
\hline $456-14-1,88-89$ & 0.24 & 1.18 & 12.01 & & \\
\hline
\end{tabular}

Normal chlorites present an usual sequence of 001 reflections. They are poorly crystallized and always associated with illites and smectites in Quaternary sediments (Holes 453, 461, and 452A).

Illites are poorly represented and often weakly crystallized. They occur in Quaternary sediments and in the Paleogene sediments in Hole 460.

Serpentines are characterized by peaks at $7.28 \AA$ and $3.65 \AA$ which remain stable upon heating, and occur at a very localized level in the Oligocene in Hole 460.

Attapulgites (palygorskites) show characteristic peaks at $10.52 \AA$ and are concentrated in the minor Eocene in Hole 460.

\section{DESCRIPTION BY HOLE}

We present the mineralogical description of the different holes from base to top, and the holes themselves are examined from west to east, from Hole 453 in the Mariana Basin to Hole 452A on the floor of the Pacific Ocean (Fig. 1).

\section{Hole 453 (Fig. 3 and Table 1)}

This hole is on the western edge of the Mariana Basin, at the foot of the West Mariana Ridge. The samples belong to Lithological Unit 1. In this hole we analyzed samples from the upper part (Cores 1-6 and 8 ), and lowest part (Cores 47 and 48).

Three mineralogical assemblages can be distinguished:

1) (Mudstone, siltstone, and very fine sandstone; lower Pliocene; Section 48,CC to 47-1). Crystallized minerals are very scarce; the amorphous phase is very abundant; and in the fine fraction the only clay minerals present are well-crystallized smectites.

2) (Clay crystal mud and vitric mud; lower Pliocene; Samples 453-8-4, 76-78 cm and 453-6-1, 24-26 cm). These would show no crystallized minerals were it not for traces of smectites in the $2 \mu \mathrm{m}$ fraction.

3) (Lithic and vitric mud; lower and upper Pleistocene; Samples $453-4-5,38-40 \mathrm{~cm}$ ). There is some detrital quartz and feldspars, especially the plagioclases but also some K-feldspars; although the clays in this sample are neither very abundant nor well crystallized, illite and chlorite appear sporadically in addition to smectites. In some samples these minerals are absent-e.g., beds of 

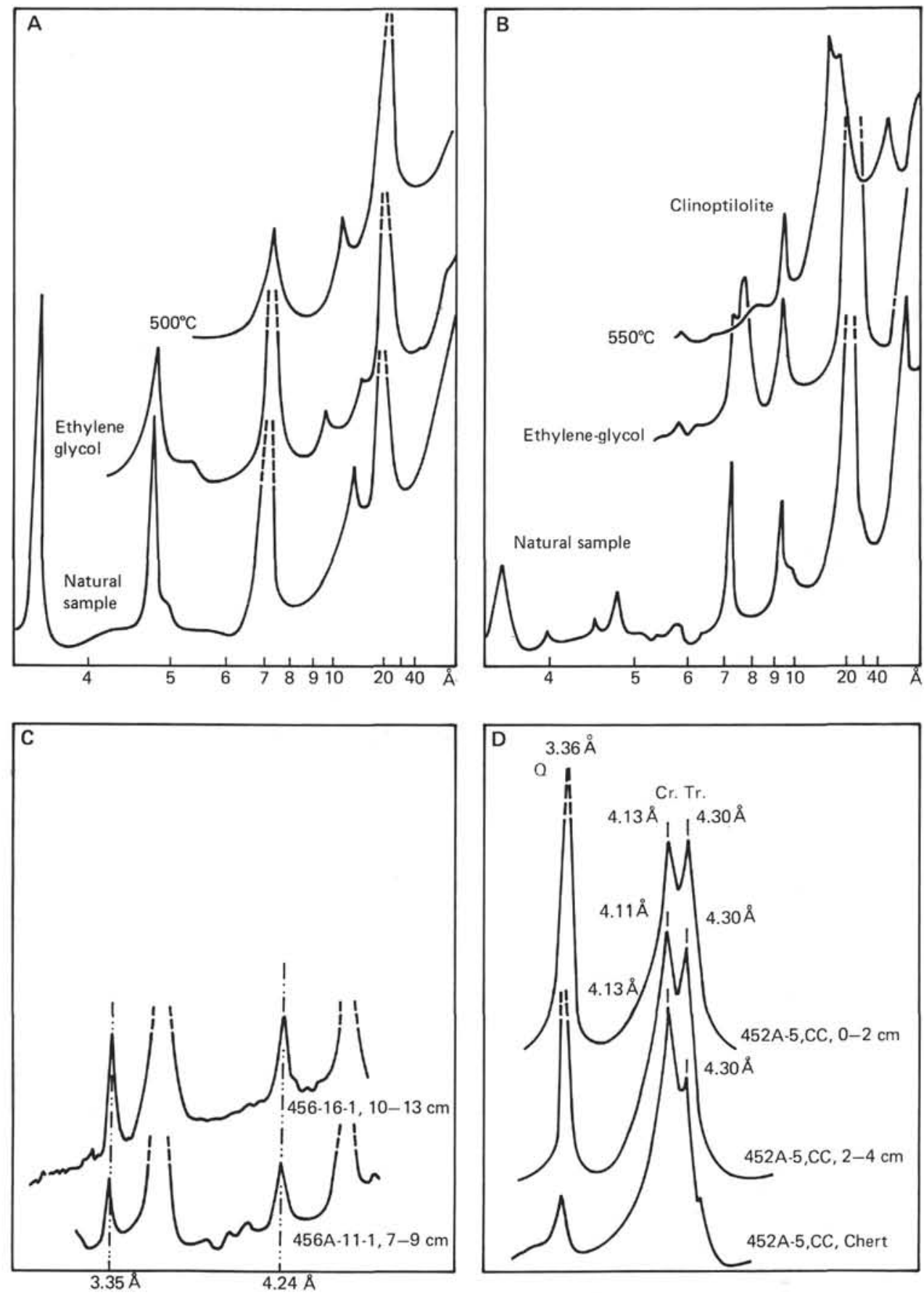

Figure 2. X-ray diffractograms. A. Fe-Mg-chlorite and (I-M) Sample 456A-10-4, 58-60 cm. B. Fe-Mgchlorite and (C-M) Sample 456A-9-13, 17-19 cm. C. Fine-grained quartzes. D. Siliceous rocks $(\mathrm{Cr} .=$ cristobalite, $\mathrm{Tr}$. = tridymite).

volcanic ash (Sample 453-4-3, 62-64 cm) and among siliceous organisms (Sample 453-1-1, 129-131 cm) (SEM observations).

\section{Hole 454A (Fig. 4 and Table 2)}

This hole is in the Mariana Trough, to the west of the central zone of spreading. The strata (lower Pleistocene vitric mudstone) are in Unit 2 and present two distinct mineralogical assemblages: noncarbonated (Core 12) and very slightly carbonated (Core 8 ). The other minerals are identical throughout the series: traces of detrital quartz, traces of $\mathrm{K}$-feldspars and principally of plagioclase; clay minerals are either absent or so slightly crystallized that they remain indeterminant. The fine fraction appears to be constituted mainly of amorphous material. It should be emphasized that Core 13, which represents the first sediments above the basalts, is completely devoid of carbonate.

\section{Holes 456 and 456A}

These are in the Mariana Trough, to the east of the central zone of spreading. 


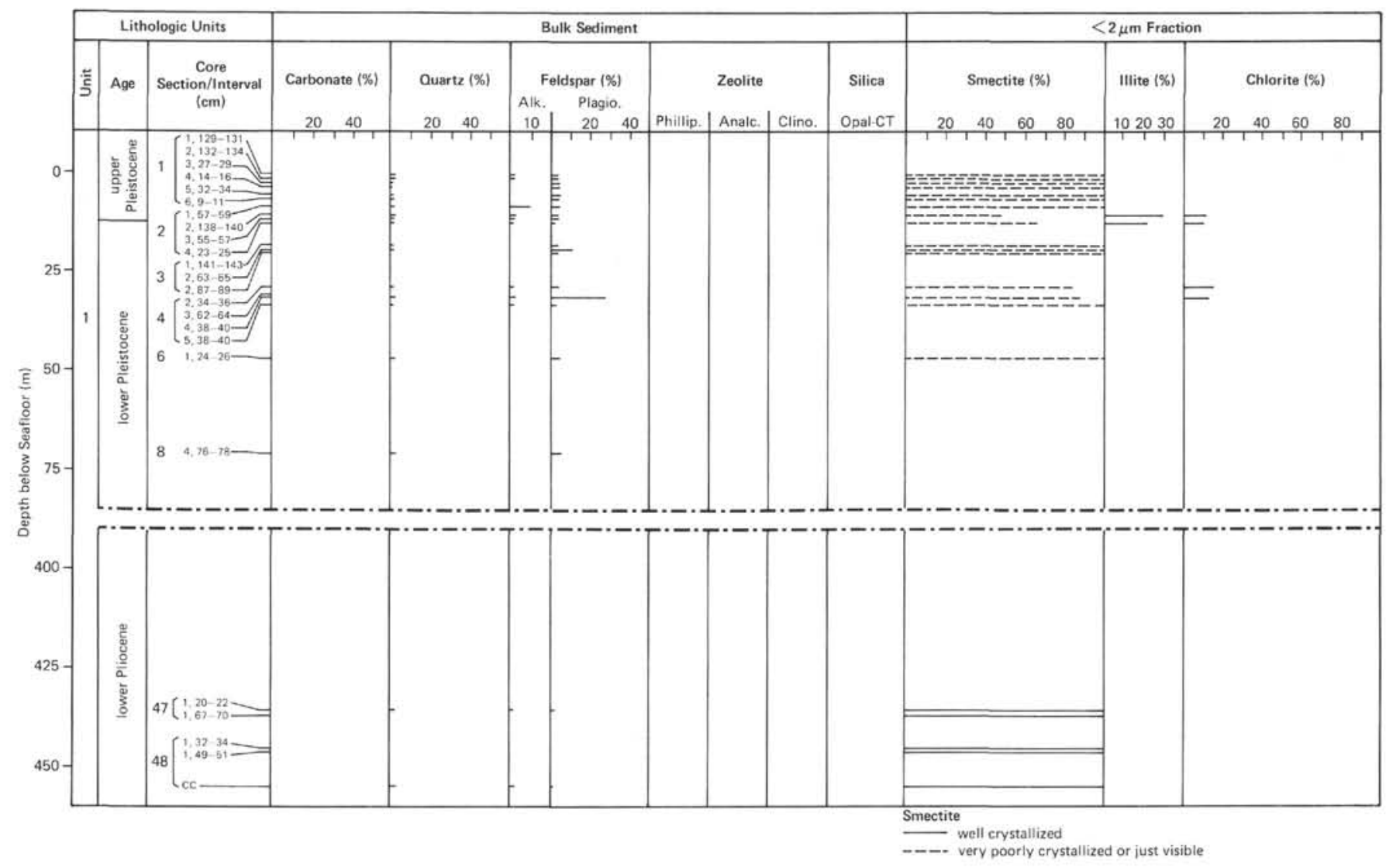

Figure 3. Mineralogical log, Hole 453.

Table 1. X-ray diffraction analysis of bulk and fine-grained $(2 \mu \mathrm{m})$ samples from Hole 453.

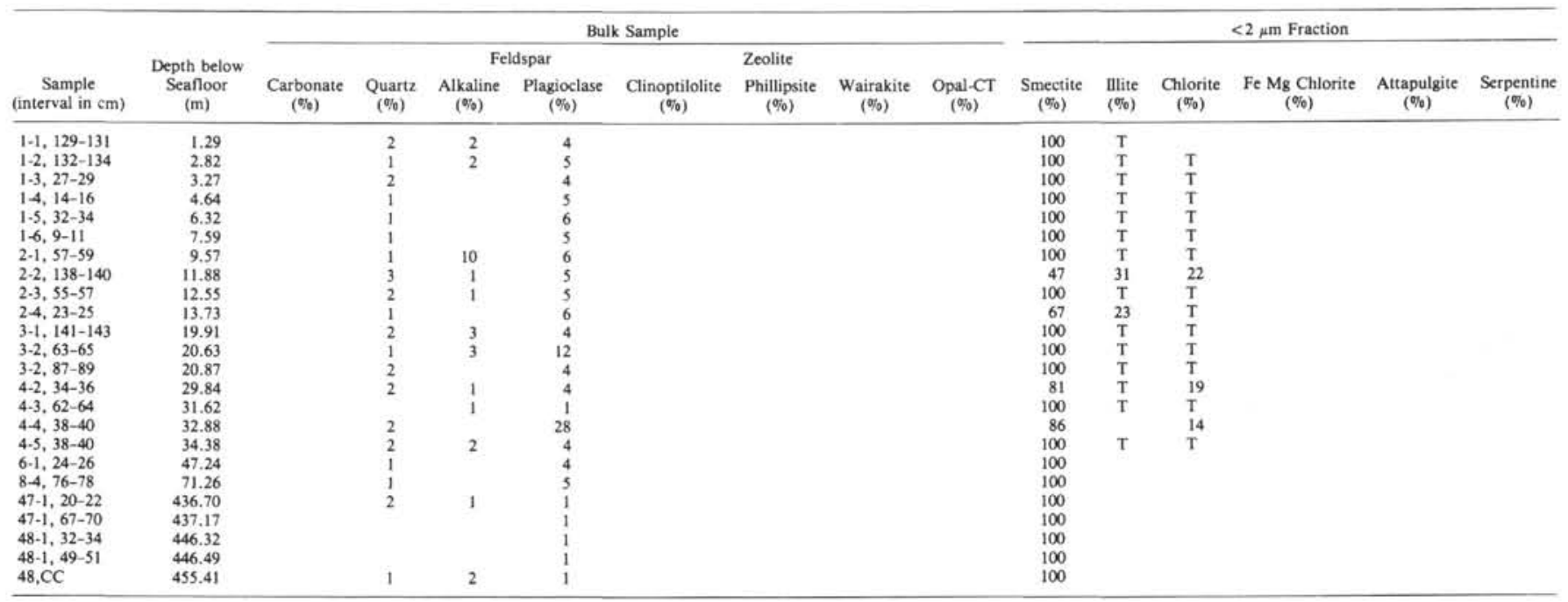

\section{Hole 456 (Fig. 5 and Table 3)}

The samples belong to Lithological Unit 2 (lower Pleistocene). Mineralogical analysis distinguishes two assemblages:

1) (Vitric mudstone and vitric marly chalk; $134.8-$ $155.19 \mathrm{~m}$; Sample 456-16-1 to 456-14-1, 69-71 cm). These samples are carbonated (maximum $24 \%$ ); quartz is present but at a value of less than $20 \%$; the plagio- clase feldspars are scarcely present; zeolites are present in small amounts, and consist chiefly of wairakite (e.g., Balshaw, this volume; Natland and Hekinian, this volume); the clays are represented by $\mathrm{Fe} \mathrm{Mg}$ chlorites (described in a later section), are abundant, and are associated with the irregular mixed-layer clays (I-M).

2) (Silty and sandy vitric tuff; at 114.87 and $95.93 \mathrm{~m}$; Samples 456-14-1, 37-39 cm and 456-12-2, 43-45 cm). These two samples show few crystallized minerals, es- 


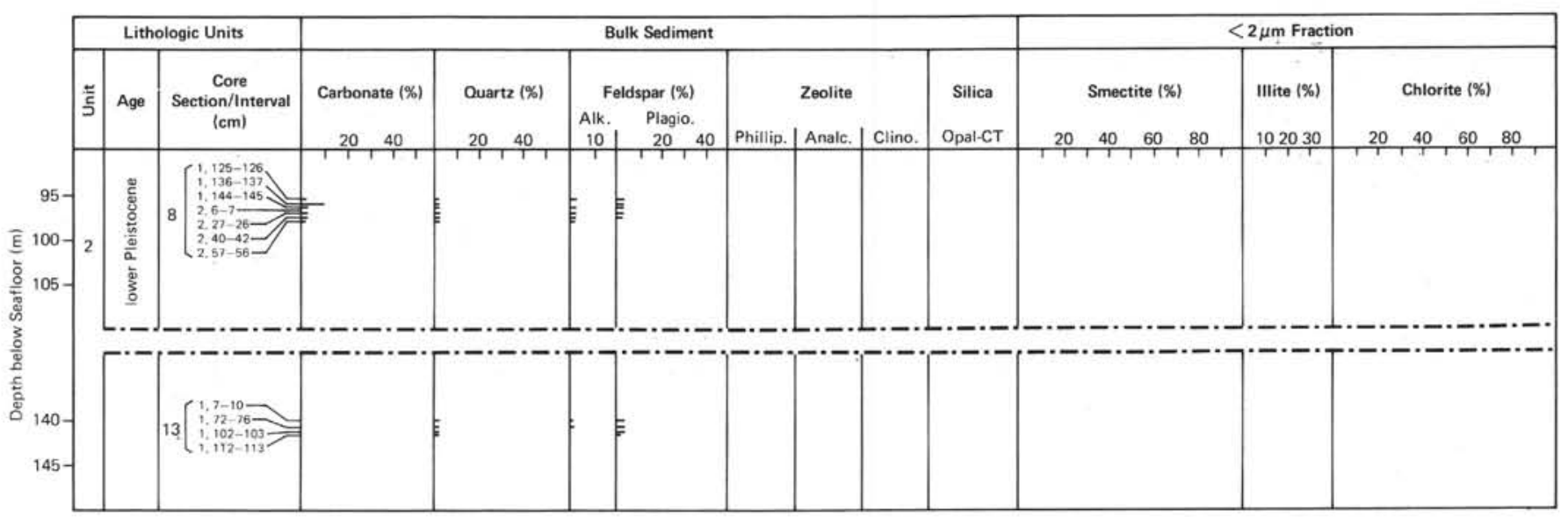

Figure 4. Mineralogical log, Hole 454A.

Table 2. X-ray diffraction analysis of bulk and fine-grained $(2 \mu \mathrm{m})$ samples from Hole 454A.

\begin{tabular}{|c|c|c|c|c|c|c|c|c|c|c|c|c|c|c|c|}
\hline \multirow[b]{3}{*}{$\begin{array}{c}\text { Sample } \\
\text { (interval in } \mathrm{cm} \text { ) }\end{array}$} & \multirow{3}{*}{$\begin{array}{l}\text { Depth below } \\
\text { Seafloor } \\
\text { (m) }\end{array}$} & \multicolumn{8}{|c|}{ Bulk Sample } & \multicolumn{6}{|c|}{$<2 \mu \mathrm{m}$ Fraction } \\
\hline & & \multicolumn{5}{|c|}{ Feldspar } & \multirow{2}{*}{$\begin{array}{l}\text { Zeolite } \\
\text { Phillipsite } \\
(\%)\end{array}$} & \multirow[b]{2}{*}{$\begin{array}{c}\text { Wairakite } \\
(\%)\end{array}$} & \multirow[b]{2}{*}{$\begin{array}{l}\text { Opal-CT } \\
(\%)\end{array}$} & \multirow[b]{2}{*}{$\begin{array}{c}\text { Smectite } \\
(\%)\end{array}$} & \multirow[b]{2}{*}{$\begin{array}{l}\text { Illite } \\
(\%)\end{array}$} & \multirow[b]{2}{*}{$\begin{array}{c}\text { Chlorite } \\
(\%)\end{array}$} & \multirow[b]{2}{*}{$\underset{(\%)}{\mathrm{Fe}} \underset{\mathrm{Mg} \text { Chlorite }}{\mathrm{M}}$} & \multirow[b]{2}{*}{$\begin{array}{l}\text { Attapulgite } \\
\qquad(\%)\end{array}$} & \multirow[b]{2}{*}{$\begin{array}{c}\text { Serpentine } \\
(\%)\end{array}$} \\
\hline & & $\begin{array}{c}\text { Carbonate } \\
(\%)\end{array}$ & $\begin{array}{l}\text { Quartz } \\
(\%)\end{array}$ & $\begin{array}{c}\text { Alkaline } \\
(\%)\end{array}$ & $\begin{array}{c}\text { Plagioclase } \\
(\%)\end{array}$ & $\begin{array}{c}\text { Clinoptilolite } \\
(\%)\end{array}$ & & & & & & & & & \\
\hline $8-1,125-126$ & 96.25 & 2 & 1 & & 3 & & & & & & & & & & \\
\hline $8-1,136-137$ & 96.36 & 4 & $i$ & & 4 & & & & & & & & & & \\
\hline $8-1,144-145$ & 96.44 & 10 & i & & 4 & & & & & & & & & & \\
\hline $8 \cdot 2,6-7$ & 96.56 & & $i$ & 2 & 4 & & & & & & & & & & \\
\hline $8-2,25-26$ & 96.75 & 3 & 1 & 2 & 2 & & & & & & & & & & \\
\hline $8-2,40-42$ & 96.90 & 4 & $i$ & & 4 & & & & & & & & & & \\
\hline $8-2,54-56$ & 97.04 & 3 & $i$ & 2 & 1 & & & & & & & & & & \\
\hline $13-1,7-10$ & 140.07 & & $i$ & 2 & 5 & & & & & & & & & & \\
\hline $13-1,72-76$ & 140.72 & & $\mathrm{i}$ & 2 & 4 & & & & & & & & & & \\
\hline $13-1,102-103$ & 141.02 & & $i$ & & 4 & & & & & & & & & & \\
\hline $13-1,112-113$ & 141.12 & & & & 2 & & & & & & & & & & \\
\hline
\end{tabular}

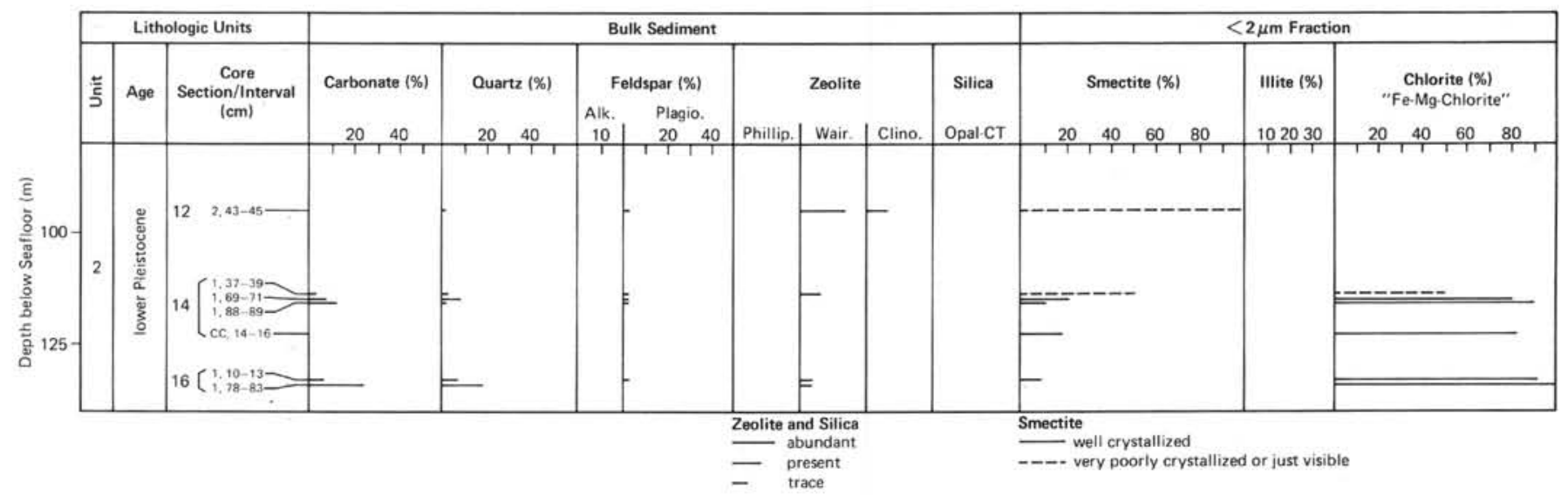

Figure 5. Mineralogical log, Hole 456.

Table 3. X-ray diffraction analysis of bulk and fine-grained $(2 \mu \mathrm{m})$ samples from Hole 456.

\begin{tabular}{|c|c|c|c|c|c|c|c|c|c|c|c|c|c|c|c|}
\hline \multirow[b]{3}{*}{$\begin{array}{c}\text { Sample } \\
\text { (interval in } \mathrm{cm} \text { ) }\end{array}$} & \multirow{3}{*}{$\begin{array}{l}\text { Depth below } \\
\text { Seafloor } \\
\text { (m) }\end{array}$} & \multicolumn{8}{|c|}{ Bulk Sample } & \multicolumn{6}{|c|}{$<2 \mu \mathrm{m}$ Fraction } \\
\hline & & \multirow[b]{2}{*}{$\begin{array}{c}\text { Carbonate } \\
(\%)\end{array}$} & \multirow[b]{2}{*}{$\begin{array}{l}\text { Quartz } \\
(\%)\end{array}$} & \multicolumn{2}{|c|}{ Feldspar } & \multirow[b]{2}{*}{$\begin{array}{c}\text { Clinoptilolite } \\
(\%)\end{array}$} & \multirow{2}{*}{$\begin{array}{l}\text { Zeolite } \\
\text { Phillipsite } \\
(\%)\end{array}$} & \multirow[b]{2}{*}{$\begin{array}{c}\text { Wairakite } \\
(\%)\end{array}$} & \multirow[b]{2}{*}{$\begin{array}{c}\text { Opal-CT } \\
(\%)\end{array}$} & \multirow[b]{2}{*}{$\begin{array}{c}\text { Smectite } \\
(\%)\end{array}$} & \multirow[b]{2}{*}{$\begin{array}{l}\text { Dlite } \\
(\%)\end{array}$} & \multirow[b]{2}{*}{$\begin{array}{l}\text { Chlorite } \\
(\%)\end{array}$} & \multirow[b]{2}{*}{$\begin{array}{c}\mathrm{Fe} \mathrm{Mg} \mathrm{Chlorite} \\
(\%)\end{array}$} & \multirow[b]{2}{*}{$\begin{array}{c}\text { Attapulgite } \\
(\%)\end{array}$} & \multirow[b]{2}{*}{$\begin{array}{c}\text { Serpentine } \\
(\%)\end{array}$} \\
\hline & & & & $\begin{array}{l}\text { Alkaline } \\
(\%)\end{array}$ & $\begin{array}{c}\text { Plagioclase } \\
(\%)\end{array}$ & & & & & & & & & & \\
\hline $12-2,43-45$ & 95.93 & & 1 & & 4 & $P$ & & A & & 100 & & & & & \\
\hline $14-1,37-39$ & 114.87 & 2 & 2 & & 4 & & & $\ddot{p}$ & & so & & 50 & & & \\
\hline $14-1,69-71$ & 115.19 & 6 & 7 & & 3 & & & & & 20 & & & 80 & & \\
\hline $14-1,88-89$ & 115.28 & 9 & 1 & & 2 & & & & & 12 & & & 88 & & \\
\hline $14, \mathrm{CC}, 14-16$ & 123.94 & & & & & & & & & 19 & & & 81 & & \\
\hline $16-1,10-13$ & 133.60 & 6 & 7 & & 1 & & & $\mathrm{~T}$ & & 6 & & & 94 & & \\
\hline $16-1,78-83$ & 134.28 & 23 & 19 & & & & & $\mathrm{~T}$ & & $T$ & & & 100 & & \\
\hline
\end{tabular}


sentially plagioclase and zeolite: clinoptilolite/heulandite and probably wairakite. These levels are not carbonated and the clay fraction is not abundant and only slightly crystallized. One can, however, recognize smectites and chlorites in Sample 456-14-1, 37-39 cm and solely smectites in Sample 456-12-2, 43-45 cm.

\section{Hole 456A (Fig. 6 and Table 4)}

The samples belong to Lithological Unit 2 (lower Pleistocene). As in Hole 456, we distinguish two mineralogical assemblages:

1) (Calcareous mudstone, marly chalk mudstone with silty and sandy tuff layers; $114.98-98.17 \mathrm{~m}$; Samples $456 \mathrm{~A}-11-1,98-100 \mathrm{~cm}$ to $456 \mathrm{~A}-9-3,17-19 \mathrm{~cm}$ ). These samples are carbonated; quartz and plagioclase are more abundant than in the preceding hole; zeolites are practically absent except for Sample 456A-9-3, $17-19 \mathrm{~cm}$; the clay phase is composed principally of $\mathrm{Fe}$ $\mathrm{Mg}$ chlorites (Plate 1, Figs. 1 and 2) and of more or less regular mixed-layer clays (I-M). Sample 456A-9-3, $17-19 \mathrm{~cm}$ contains a regular mixed-layer clay $(\mathrm{C}-\mathrm{M})$.

2) (Muddy, silty, and sandy vitric tuff; $96.08-68.43$ $\mathrm{m}$; Samples 456A-9-1, 108-110 cm to 456A-6-2, 43-45 $\mathrm{cm}$ ). The samples are poorly crystallized and show traces of quartz, plagioclase, and occasionally zeolite; the clay phase, contrary to that in Hole 456, is highly crystallized in the form of smectites.

Some characteristics of Hole 456 and $456 \mathrm{~A}$ merit emphasis.

1. Compared to Hole $454 \mathrm{~A}$, the Hole 456 and $456 \mathrm{~A}$ samples above the basalt are carbonated, which confirms the observation made aboard ship regarding the presence of the recrystallization of carbonates as much in the sediments as in the basalts (see Site 456 Report, this volume).

2. The quartz is not exclusively detrital; indeed, the $<2 \mu \mathrm{m}$ fraction contains quartz in which the relative intensity of the peaks at $4.24 \AA$ and $3.35 \AA$ is not of a regular occurrence. The peak at $4.24 \AA$ is more important than at $3.35 \AA$ (Fig. 2C), which we interpret to indicate the presence of authigenic quartz.

3. Fe $\mathrm{Mg}$ chlorites occurred abundantly in both holes in samples immediately above, or intercalated with, basalts.

4. The zeolites are wairakite, inferred by Natland and Hekinian (this volume) to have formed at temperatures $>200^{\circ} \mathrm{C}$ by the action of hydrothermal fluids.

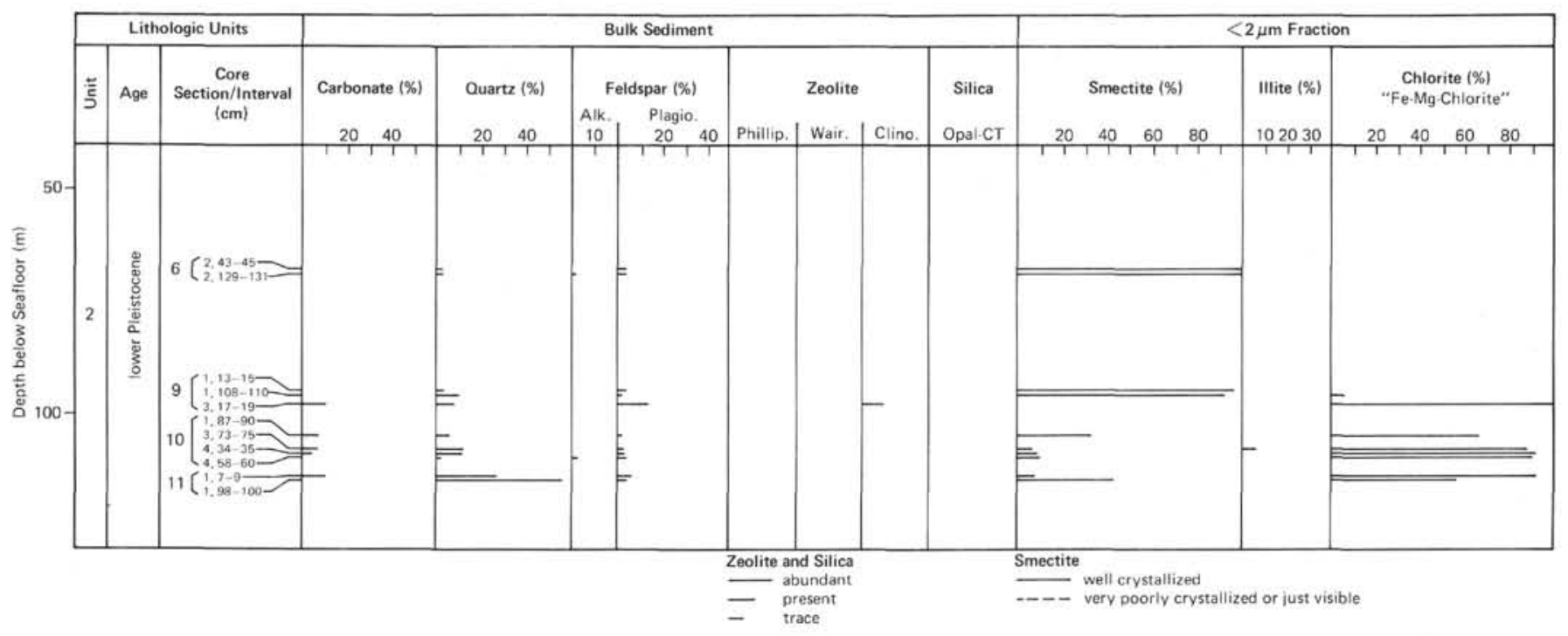

Figure 6. Mineralogical log, Hole 456A.

Table 4. X-ray diffraction analysis of bulk and fine-grained $(2 \mu \mathrm{m})$ samples from Hole 456A.

\begin{tabular}{|c|c|c|c|c|c|c|c|c|c|c|c|c|c|c|c|}
\hline \multirow[b]{3}{*}{$\begin{array}{c}\text { Sample } \\
\text { (interval in } \mathrm{cm} \text { ) }\end{array}$} & \multirow{3}{*}{$\begin{array}{l}\text { Depth below } \\
\text { Seafloor } \\
\text { (m) }\end{array}$} & \multicolumn{8}{|c|}{ Bulk Sample } & \multicolumn{6}{|c|}{$<2 \mu \mathrm{m}$ Fraction } \\
\hline & & \multirow[b]{2}{*}{$\begin{array}{c}\text { Carbonate } \\
(\%)\end{array}$} & \multirow[b]{2}{*}{$\begin{array}{l}\text { Quartz } \\
(\%)\end{array}$} & \multicolumn{2}{|c|}{ Feldspar } & \multirow[b]{2}{*}{$\begin{array}{c}\text { Clinoptilolite } \\
(\%)\end{array}$} & \multirow{2}{*}{$\begin{array}{l}\text { Zeolite } \\
\text { Phillipsite } \\
\qquad(\%)\end{array}$} & \multirow[b]{2}{*}{$\begin{array}{c}\text { Wairakite } \\
(\%)\end{array}$} & \multirow[b]{2}{*}{$\begin{array}{c}\text { Opal-CT } \\
(\%)\end{array}$} & \multirow[b]{2}{*}{$\begin{array}{c}\text { Smectite } \\
(\%)\end{array}$} & \multirow[b]{2}{*}{$\begin{array}{l}\text { Illite } \\
(\%)\end{array}$} & \multirow[b]{2}{*}{$\begin{array}{c}\text { Chlorite } \\
\left(\sigma_{0}\right)\end{array}$} & \multirow[b]{2}{*}{$\begin{array}{c}\mathrm{Fe} \mathrm{Mg}_{8} \text { Chlorite } \\
(\%)\end{array}$} & \multirow[b]{2}{*}{$\begin{array}{c}\text { Attapulgite } \\
(\%)\end{array}$} & \multirow[b]{2}{*}{$\begin{array}{c}\text { Serpentine } \\
(\%)\end{array}$} \\
\hline & & & & $\begin{array}{c}\text { Alkaline } \\
(\%)\end{array}$ & $\begin{array}{l}\text { Plagioclase } \\
(\%)\end{array}$ & & & & & & & & & & \\
\hline $6-2,43-45$ & 68.43 & & 2 & & 5 & & & & & 100 & & & & & \\
\hline $6-2,129-131$ & 69.29 & & 3 & 2 & 3 & & & & & -100 & & & & & \\
\hline $9-1,13-15$ & 95.13 & & 4 & & 4 & & & & & 100 & & & & & \\
\hline $9-1,108-110$ & 96.08 & 1 & 10 & & 3 & & & & & 93 & & & 7 & & \\
\hline $9-3,17-19$ & 98.17 & 9 & 7 & & 15 & $\mathbf{P}$ & & & & & & & 100 & & \\
\hline $10-1,87-90$ & 105.37 & 6 & 5 & & 2 & & & & & 36 & & & 64 & & \\
\hline $10-3,73-75$ & 108.23 & 6 & 11 & & 3 & & & & & 7 & 7 & & 86 & & \\
\hline $10-4,34-36$ & 109.34 & 4 & 11 & & 4 & & & & & 11 & & & 89 & & \\
\hline $10-4,58-60$ & 109.58 & & 2 & 1 & 5 & & & & & 9 & & & 91 & & \\
\hline $11-1,7-9$ & 114.07 & 10 & 26 & & 7 & & & & & 7 & & & 93 & & \\
\hline $11-1,98-100$ & 114,98 & & 56 & & 3 & & & & & 43 & & & 57 & & \\
\hline
\end{tabular}




\section{Hole 458 (Fig. 7 and Table 5)}

This hole is to the east of the Mariana Ridge in the trench arc complex. Five lower Oligocene samples were studied consisting of vitric siltstone, sandstone, and altered vitric ash. They were selected from under a thick carbonated Oligo-Miocene series above the upper preEocene basement of bronzite andesites in Hole 459.

Viewed as a whole, the amorphous phase is dominant. One sample only is poorly carbonated; zeolites are present (phillipsite); the clay fraction, which is highly crystallized, consists of smectites only.

\section{Hole 459B (Fig. 8 and Table 6)}

This hole is on the edge of the trench on the upper part of the trench-slope break. The sediments belong to four different lithological units.

1) Unit 6: (Altered basalt and silicified claystone; pre-upper Eocene; Samples 459B-60-1, 15-16 cm and 459B-60-1, 74-75 cm). These two samples are characterized by a high content of amorphous products, some detrital quartz, and plagioclase and zeolite of phillipsite and clinoptilolite/heulandite types; the clays are highly crystallized in the form of smectites.

2) Unit 5: (Claystone and chert; lower upper Eocene; Samples 459B-50-1, 65-67 cm and 459B-50-1, 130-132 $\mathrm{cm})$. These samples are characterized by an abundance of crystallized silica in the form of opal-CT accompanied by small quantities of detrital quartz, plagioclase, and some clinoptilolite/heulandite zeolite; the clays are always well crystallized in smectites.

3) Unit 4: (Claystone; lower Oligocene; Sample 459B-58-1, 59-60 cm) is characterized (according to the one sample) by the total absence of crystallized minerals. This sample constitutes a bed of altered vesicular ash, as is shown in the SEM photograph (see Plate 1, Fig. 3).

4) Unit 3: Samples $459 \mathrm{~B}-57-1,26-28 \mathrm{~cm}$ to $459 \mathrm{~B}-$ $11-2,59-60 \mathrm{~cm}$ is divided into three sub-units. This assemblage presents two mineralogical suites:

1. (Vitric marly nannofossil chalk and vitric mudstone; upper Oligocene; Samples 459B-57-1, 26-28 cm to $459 \mathrm{~B}-50-2,9-11 \mathrm{~cm}$ of Sub-unit 3C). Rich in carbonates with the exception of Sample 459B-50-2, 9-11 cm; the clays are highly crystallized in smectites.

2. (Mudstone contaminated by volcaniclastics and vitric marly nannofossil chalks; lower Miocene to middle Miocene; Samples 459B-42-2, 51-53 cm to 459B-11$2,59-60 \mathrm{~cm}$, of Sub-units $3 \mathrm{~B}$ and $3 \mathrm{~A}$ ). Characterized by an assemblage rich in plagioclase with traces of carbonates, detrital quartz, and phillipsite. The clay phase is either very slightly or not at all crystallized; the only identifiable mineral is smectite.

One sample (459B-35-1, 101-103 cm) shows no crystallized material and corresponds to an ash bed (SEM observation).

\section{Holes 460 and $460 \mathrm{~A}$}

These were drilled in the inner wall of the Mariana Trench, a few kilometers from its axis, and at the base of the slope.

\section{Hole 460 (Fig. 9 and Table 7)}

The sediments in this hole, altered vitric tuff and zeolitic mud, upper middle Eocene to upper Oligocene, belong to Unit 3. Its dominant characteristics are as fol-

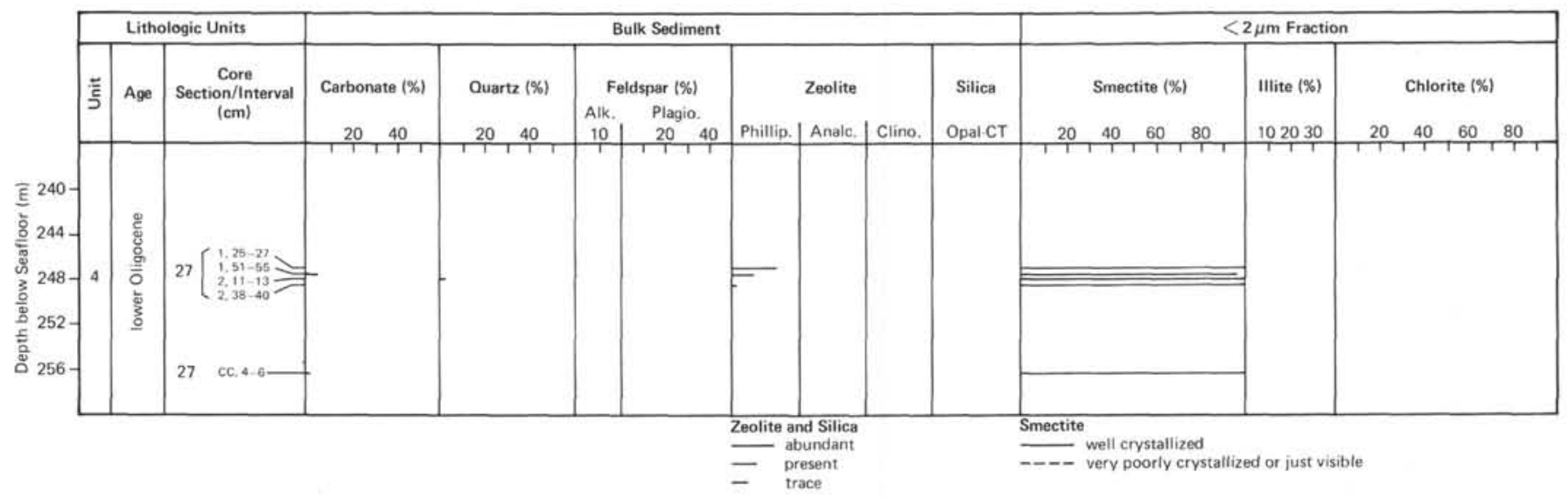

Figure 7. Mineralogical log, Hole 458.

Table 5. X-ray diffraction analysis of bulk and fine-grained $(2 \mu \mathrm{m})$ samples from Hole 458.

\begin{tabular}{|c|c|c|c|c|c|c|c|c|c|c|c|c|c|c|c|}
\hline \multirow[b]{3}{*}{$\begin{array}{c}\text { Sample } \\
\text { (interval in } \mathrm{cm} \text { ) }\end{array}$} & \multirow{3}{*}{$\begin{array}{l}\text { Depth below } \\
\text { Seafloor } \\
\text { (m) }\end{array}$} & \multicolumn{8}{|c|}{ Bulk Sample } & \multicolumn{6}{|c|}{$<2 \mu$ m Fraction } \\
\hline & & \multirow[b]{2}{*}{$\begin{array}{c}\text { Carbonate } \\
(\%)\end{array}$} & \multirow[b]{2}{*}{$\underset{(\%)}{\text { Quartz }}$} & \multicolumn{2}{|c|}{ Feldspar } & \multirow[b]{2}{*}{$\begin{array}{l}\text { Clinoptilolite } \\
(\%)\end{array}$} & \multirow{2}{*}{$\begin{array}{l}\text { Zeolite } \\
\text { Phillipsite } \\
(\%)\end{array}$} & \multirow[b]{2}{*}{$\begin{array}{c}\text { Analcime } \\
(\%)\end{array}$} & \multirow[b]{2}{*}{$\begin{array}{c}\text { Opal-CT } \\
(\%)\end{array}$} & \multirow[b]{2}{*}{$\begin{array}{c}\text { Smectite } \\
(\%)\end{array}$} & \multirow[b]{2}{*}{$\begin{array}{l}\text { Illite } \\
(\%)\end{array}$} & \multirow[b]{2}{*}{$\begin{array}{c}\text { Chlorite } \\
(\%)\end{array}$} & \multirow[b]{2}{*}{$\underset{(\%)}{\mathrm{Fe} \mathrm{Mg} \mathrm{Chlorite}}$} & \multirow[b]{2}{*}{$\begin{array}{c}\text { Attapulgite } \\
(\%)\end{array}$} & \multirow[b]{2}{*}{$\begin{array}{l}\text { Serpentine } \\
(\%)\end{array}$} \\
\hline & & & & $\begin{array}{c}\text { Alkaline } \\
(\%)\end{array}$ & $\begin{array}{l}\text { Plagioclase } \\
(\%)\end{array}$ & & & & & & & & & & \\
\hline $27-1,25-27$ & 247.25 & & & & 20 & & & & & 100 & & & & & \\
\hline $27-1,51-53$ & 247.51 & 5 & & & 10 & & & & & 100 & & & & & \\
\hline $27-2,11-13$ & 248.61 & & 1 & & $T$ & & & & & 100 & & & & & \\
\hline $27-2,38-40$ & 248.88 & & & & 2 & & & & & 100 & & & & & \\
\hline $27, \mathrm{CC}, 4-6$ & 256.34 & 1 & & & $T$ & & & & & 100 & & & & & \\
\hline
\end{tabular}




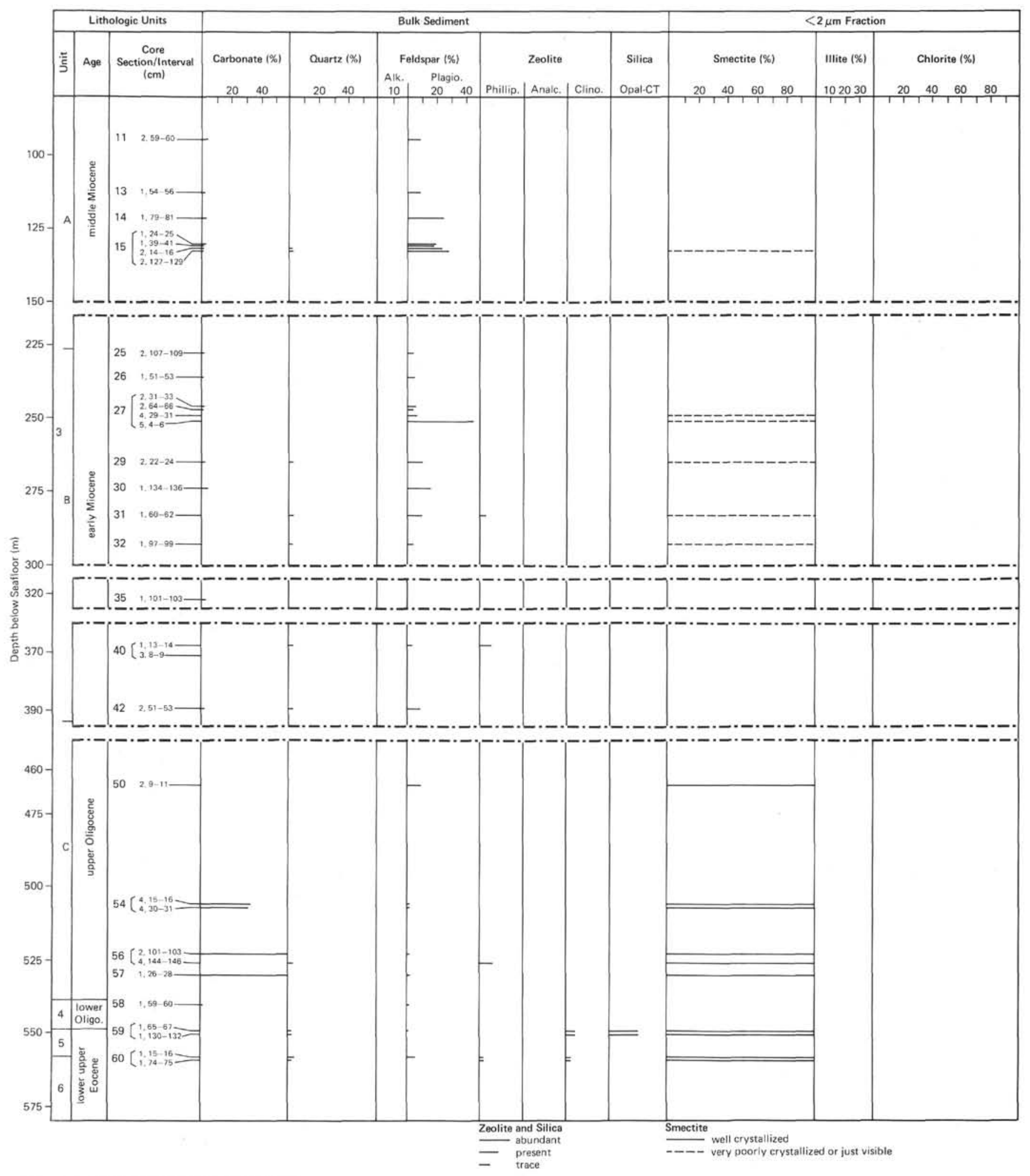

Figure 8. Mineralogical log, Hole 459B. 
Table 6. X-ray diffraction analysis of bulk and fine-grained $(2 \mu \mathrm{m})$ samples from Hole 459B.

\begin{tabular}{|c|c|c|c|c|c|c|c|c|c|c|c|c|c|c|c|}
\hline \multirow[b]{3}{*}{$\begin{array}{c}\text { Sample } \\
\text { (interval in } \mathrm{cm} \text { ) }\end{array}$} & \multirow{3}{*}{$\begin{array}{l}\text { Depth below } \\
\text { Seafloor } \\
\text { (m) }\end{array}$} & \multicolumn{8}{|c|}{ Bulk Sample } & \multicolumn{6}{|c|}{$<2 \mu \mathrm{m}$ Fraction } \\
\hline & & \multicolumn{5}{|c|}{ Feldspar } & \multicolumn{3}{|l|}{ Zeolite } & \multirow[b]{2}{*}{$\begin{array}{c}\text { Smectite } \\
(\%)\end{array}$} & \multirow[b]{2}{*}{$\begin{array}{l}\text { Mllite } \\
(\%)\end{array}$} & \multirow[b]{2}{*}{$\begin{array}{c}\text { Chlorite } \\
(\%)\end{array}$} & \multirow[b]{2}{*}{$\begin{array}{c}\mathrm{Fe} \mathrm{Mg} \text { Chlorite } \\
(\%)\end{array}$} & \multirow[b]{2}{*}{$\begin{array}{c}\text { Attapulgite } \\
(\%)\end{array}$} & \multirow[b]{2}{*}{$\begin{array}{c}\text { Serpentine } \\
(\%)\end{array}$} \\
\hline & & $\begin{array}{c}\text { Carbonate } \\
(\%))\end{array}$ & $\begin{array}{c}\text { Quartz } \\
\left(\%_{0}\right)\end{array}$ & $\begin{array}{c}\text { Alkaline } \\
\left(\%_{0)}\right)\end{array}$ & $\begin{array}{c}\text { Plagioclase } \\
\left(\sigma^{\circ}\right)\end{array}$ & $\begin{array}{c}\text { Cinoptilolite } \\
(\%)\end{array}$ & $\begin{array}{c}\text { Phillipsite } \\
\left(\%_{0}\right)\end{array}$ & $\underset{(\%)}{\text { Analcime }}$ & $\begin{array}{c}\text { Opal-CT } \\
(\%)\end{array}$ & & & & & & \\
\hline $11-2,59-60$ & 95.09 & 4 & & & 10 & & & & & & & & & & \\
\hline $13-1,54-56$ & 113.04 & T & & & 10 & & & & & & & & & & \\
\hline $14-1,79-81$ & 122.29 & 4 & & & 25 & & & & & & & & & & \\
\hline $15-1,24-25$ & 131.24 & & $\mathrm{~T}$ & & 20 & & & & & & & & & & \\
\hline $15-1,39-41$ & $\begin{array}{l}131.39 \\
130.14\end{array}$ & 4 & & & 20 & & & & & & & & & & \\
\hline $\begin{array}{l}15-2,14-16 \\
15-2,127-129\end{array}$ & 132.64 & 2 & 1 & & 25 & & & & & & & & & & \\
\hline $\begin{array}{r}15-2,127-129 \\
25-2,107-129\end{array}$ & $\begin{array}{l}133.77 \\
228.57\end{array}$ & 2 & 1 & & $\begin{array}{l}30 \\
5\end{array}$ & & & & & 100 & & & & & \\
\hline $\begin{array}{l}25-2,107-109 \\
26-1,51-53\end{array}$ & $\begin{array}{l}2288.57 \\
236.01\end{array}$ & $T_{T}^{1}$ & & & $\begin{array}{l}5 \\
6\end{array}$ & & & & & & & & & & \\
\hline $27-2,31-33$ & 246.81 & 2 & & & 5 & & & & & & & & & & \\
\hline $27-2,64-66$ & 247.14 & 1 & & & 4 & & & & & & & & & & \\
\hline $27-4,29-31$ & 249.79 & & & & 6 & & & & & 100 & & & & & \\
\hline $27-5,4-6$ & 251.04 & T & $\mathrm{T}$ & & 45 & & & & & 100 & & & & & \\
\hline $29-2,22-24$ & 265.72 & 2 & $i$ & & 10 & & & & & 100 & & & & & \\
\hline $30-1,134-136$ & 274.84 & 3 & $\mathrm{~T}$ & & is & & & & & & & & & & \\
\hline $31-1,60-62$ & 283.60 & & i & & 10 & & $\mathrm{~T}$ & & & 100 & & & & & \\
\hline $32-1,97-99$ & 293.47 & T & $i$ & & 3 & & & & & 100 & & & & & \\
\hline $35-1,101-103$ & 322.01 & 2 & & & & & & & & & & & & & \\
\hline $40-1,13-14$ & 368.63 & $\mathrm{~T}$ & 1 & & 4 & & $P$ & & & & & & & & \\
\hline $\begin{array}{l}40-3,8-9 \\
42-2,51-53\end{array}$ & $\begin{array}{l}371.58 \\
389.51\end{array}$ & & $\mathrm{~T}$ & & ${ }_{10}^{T}$ & & & & & & & & & & \\
\hline $\begin{array}{l}42 \cdot 2,51-53 \\
50-2,9-51\end{array}$ & $\begin{array}{l}389.51 \\
44509\end{array}$ & 1 & 1 & & 10 & & & & & 100 & & & & & \\
\hline $54-4,15-16$ & $\begin{array}{l}465.09 \\
506.15\end{array}$ & 34 & $T$ & & 2 & & & & & 100 & & & & & \\
\hline $54-4,30-31$ & $\begin{array}{l}506.30 \\
506\end{array}$ & $\begin{array}{l}34 \\
32\end{array}$ & $\mathrm{~T}$ & & 3 & & & & & 100 & & & & & \\
\hline $56-2,101-103$ & $\begin{array}{l}523.01 \\
52301\end{array}$ & $\begin{array}{l}32 \\
63\end{array}$ & $\tau$ & & $\frac{3}{2}$ & & & & & 100 & & & & & \\
\hline $56-4,144-146$ & 526.44 & & 2 & & & & $\mathbf{P}$ & & & 100 & & & & & \\
\hline $57-1,26-28$ & 530.26 & 65 & $\mathrm{~T}$ & & 2 & & & & & 100 & & & & & \\
\hline $58-1,59-60$ & 540.09 & 1 & $T$ & & 1 & & & & & & & & & & \\
\hline $59-1,65-67$ & 549.65 & & $i$ & & 3 & T & & & A & 100 & & & & & \\
\hline $59-1,130-132$ & 550.30 & $\begin{array}{lll}T & \end{array}$ & i & & 3 & $\mathrm{~T}$ & & & A & 100 & & & & & \\
\hline $60-1,15-16$ & 558.65 & & 3 & & 6 & T & $\mathrm{T}$ & & & 100 & & & & & \\
\hline $60-1,74-75$ & 559.24 & & 1 & & & $\mathrm{~T}$ & $T$ & & & 100 & & & & & \\
\hline
\end{tabular}

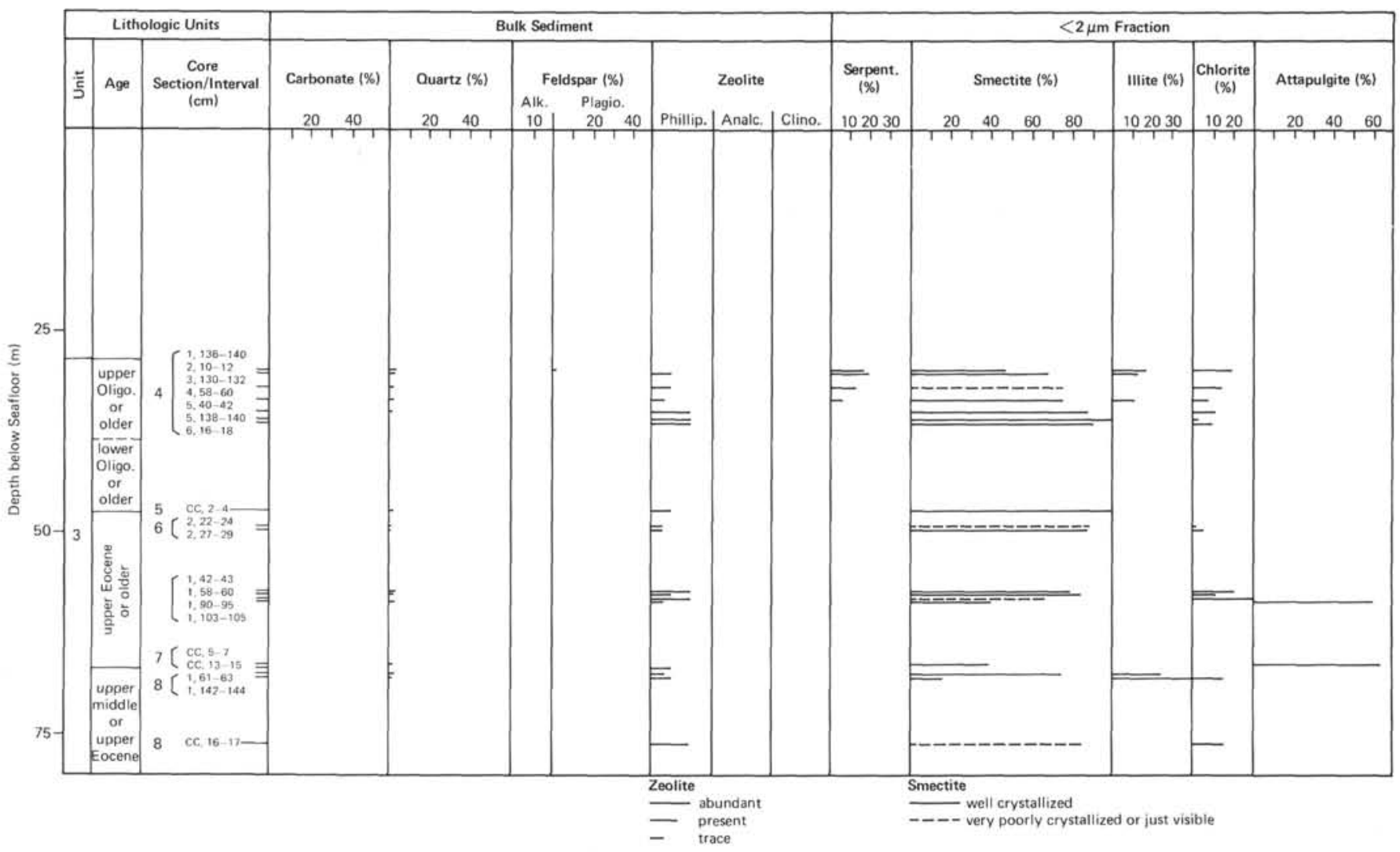

Figure 9. Mineralogical log, Hole 460. 
Table 7. X-ray diffraction analysis of bulk and fine-grained $(2 \mu \mathrm{m})$ samples from Hole 460.

\begin{tabular}{|c|c|c|c|c|c|c|c|c|c|c|c|c|c|c|c|}
\hline \multirow[b]{3}{*}{$\begin{array}{l}\text { Sample } \\
\text { (interval in } \mathrm{cm} \text { ) }\end{array}$} & \multirow{3}{*}{$\begin{array}{l}\text { Depth below } \\
\text { Seafloor } \\
\text { (m) }\end{array}$} & \multicolumn{8}{|c|}{ Bulk Sample } & \multicolumn{6}{|c|}{$<2 \mu \mathrm{m}$ Fraction } \\
\hline & & \multicolumn{5}{|c|}{ Feldspar } & \multicolumn{3}{|l|}{ Zeolite } & & & & & & \\
\hline & & $\begin{array}{c}\text { Carbonate } \\
(\%)\end{array}$ & $\underset{(\%)}{\text { Quartz }}$ & $\begin{array}{c}\text { Alkaline } \\
(\%)\end{array}$ & $\begin{array}{c}\text { Plagioclase } \\
(\%)\end{array}$ & $\begin{array}{c}\text { Clinoptilolite } \\
(\%)\end{array}$ & $\begin{array}{l}\text { Phillipsite } \\
\qquad(\%)\end{array}$ & $\begin{array}{c}\text { Analcime } \\
(\%)\end{array}$ & $\begin{array}{c}\text { Opal-CT } \\
(\%)\end{array}$ & $\begin{array}{c}\text { Smectite } \\
(\%)\end{array}$ & $\begin{array}{l}\text { Illite } \\
(\%)\end{array}$ & $\begin{array}{c}\text { Chlorite } \\
\left(F_{0}\right)\end{array}$ & $\begin{array}{c}\mathrm{Fe} \mathrm{Mg} \mathrm{Chlorite} \\
(\%)\end{array}$ & $\begin{array}{l}\text { Attapulgite } \\
\qquad(\%)\end{array}$ & $\begin{array}{c}\text { Serpentine } \\
(\%)\end{array}$ \\
\hline $4-1,136-140$ & 29.86 & & 2 & & 1 & & & & & 46 & 18 & 20 & & & 16 \\
\hline $4-2,10-12$ & 30.10 & & 2 & & & & $\mathrm{P}$ & & & 68 & 14 & & & & 18 \\
\hline $4-3,130-132$ & 32.80 & & 2 & & & & $\mathrm{p}$ & & & 73 & & 15 & & & 12 \\
\hline $4-4,58-60$ & 33.58 & & 1 & & & & T & & & 75 & 12 & 8 & & & 5 \\
\hline $4-5,40-42$ & 34.90 & & 2 & & & & A & & & 88 & $\mathrm{~T}$ & 12 & & & $\mathrm{~T}$ \\
\hline $4-5,138-140$ & 35.88 & & $\mathrm{~T}$ & & & & A & & & 98 & $\mathrm{~T}$ & 2 & & & $\mathrm{~T}$ \\
\hline $4-6,16-18$ & 36.16 & & $\mathrm{~T}$ & & & & A & & & 90 & $\mathrm{~T}$ & 10 & & & \\
\hline 5.CC, $2-4$ & 47.02 & & i & & & & $\mathrm{P}$ & & & 100 & & $\mathrm{~T}$ & & & \\
\hline $6-2,22-24$ & 49.22 & & 1 & & & & $\mathrm{~T}$ & & & 100 & & & & & \\
\hline $6-2,27-29$ & 49.27 & & $i$ & & & & $\dot{T}$ & & & 94 & & 6 & & & \\
\hline $7-1,42-43$ & 57.42 & & 2 & & & & A & & & 78 & & 22 & & & \\
\hline $7-1,58-60$ & 57.58 & & 2 & & & & $\mathrm{p}$ & & & 83 & 6 & 11 & & & \\
\hline $71,90-95$ & 57.90 & & & & & & A & & & 70 & & 30 & & $\mathrm{~T}$ & \\
\hline $7-1,103-105$ & 58.03 & & 4 & & & & $\mathrm{~T}$ & & & 37 & & & & 63 & \\
\hline 7.CC. $5-7$ & 66.05 & & 2 & & & & $\dot{\mathrm{p}}$ & & & 38 & & & & 62 & \\
\hline $7, \mathrm{CC}, 13-15$ & 66.13 & & & & & & & & & 85 & & 15 & & & \\
\hline $8-1,61-63$ & 67.11 & & 2 & & & & T & & & 75 & 25 & & & & \\
\hline $8-1,142-144$ & 67.92 & & $i$ & & & & $\mathrm{p}$ & & & 18 & 47 & 18 & & & \\
\hline $8, \mathrm{CC}, 16-17$ & 75.66 & & & & & & A & & & 83 & & 17 & & & \\
\hline
\end{tabular}

lows: The amorphous phase is important; the crystalline phase includes traces of detrital quartz, phillipsite, and well-crystallized clay represented by abundant smectites, chlorites, illites, and very sporadic attapulgites.

By comparing the stratigraphic information (on the basis of nannoplankton) and mineralogical variations, the following episodes can be recognized:

1) Core 8 (upper middle or upper Eocene) is composed mainly of zeolites (phillipsite) and of smectites together with illites and chlorites.

2) Core 7 (upper Eocene or older) shows traces of detrital quartz, phillipsite, smectites, illites, and chlorites; several microstrata are very rich in attapulgite (Samples $460-7, \mathrm{CC}, 5-7 \mathrm{~cm}$ and 460-7-1, 103-105 cm) (Plate 1, Fig. 4).

3) Core 6 (lower Oligocene and upper Eocene, according to radiolarian studies) is less rich in phillipsites; the clays are mainly smectites.

4) Core 5 (lower Oligocene or older) shows the same mineralogical characteristics as Core 6 .

5) Core 4 (upper Oligocene or older) is marked by a small quantity of quartz, phillipsite, and clays (a high proportion of smectites associated with illite, chlorite, and serpentine).

\section{Hole 460A (Fig. 10 and Table 8)}

The sediments studied cover Units 3, 2, 1 and can be re-grouped into 3 assemblages.

1) Unit 3: (Altered basalts; unspecified age; Section $460 \mathrm{~A}-8, \mathrm{CC}$ ). The minerals are hardly crystallized; phillipsites are discernible; the clays are poorly crystallized; smectites are barely visible.

2) Unit 2: (Vitric mud, mudstone, and claystone; unspecified age; Sections 460A-7-2 and 460A-7-1). Slightly crystallized; the plagioclases are relatively abundant; phillipsites are present; clays consist of poorly crystallized smectites.

3) Unit 1: (Siliceous mud and vitric mud; Pleistocene; Sample 460A-1-1, 16-17 cm). Minerals include some traces of quartz and plagioclases; the clays are ab- sent. This sample is rich in siliceous organisms (SEM observation).

Comparing Hole $460 \mathrm{~A}$ to Hole 460 one notes a similarity between the mineralogical suites in Unit 3 . In addition the Unit 2 suite with plagioclases is related to the one recovered in Units $3 \mathrm{~A}$ and $3 \mathrm{~B}$ in Hole 459B. In the absence of proper stratigraphic information for Hole 460A these comparisons may imply an Oligocene age for Unit 3 and a Miocene age for Unit 2; the structural complexity of Hole $460 \mathrm{~A}$ should be emphasized (see site 460 report, this volume).

\section{Holes 461 and 461A (Fig. 11 and Table 9)}

These holes are situated at the base of the inner wall of the Mariana Trench. The sediments recovered in Hole 461 are described as belonging to Unit 1 (crystal vitric mud) by the shipboard party (see site report, this volume), whereas those from Hole 461A belong to Unit 2 (crystal vitric mud and crystal siliceous ooze). They are uppermost Quaternary in age.

We studied one sample from each site. Both lack carbonate and have a small quantity of detrital quartz, plagioclase, and traces of zeolite; the clays are poorly crystallized and represented by a mixed suite of smectites, illites, and chlorites.

\section{Hole 452A (Fig. 12 and Table 10)}

This hole is on the Pacific Plate. From base to top are two large mineralogical assemblages:

1) (Chert; Upper Cretaceous; Section $452 \mathrm{~A}-5, \mathrm{CC}$ ) is characterized by a great abundance of crystallized silica in the form of opal-CT and by quartz, which appears to be more abundant in the less compact levels (Fig. 2D); only Sample $452 \mathrm{~A}-5, \mathrm{CC}, 0-2 \mathrm{~cm}$ shows a well-crystallized clay phase (smectites).

2) (Pelagic clay; Pleistocene). Upper samples contain little quartz. K-feldspar and plagioclase are present. Zeolites are relatively abundant and consist of phillipsite and some rare clinoptilolite/heulandite; the clays are represented by abundant smectite, common illite, and traces of chlorite increasing upward. 


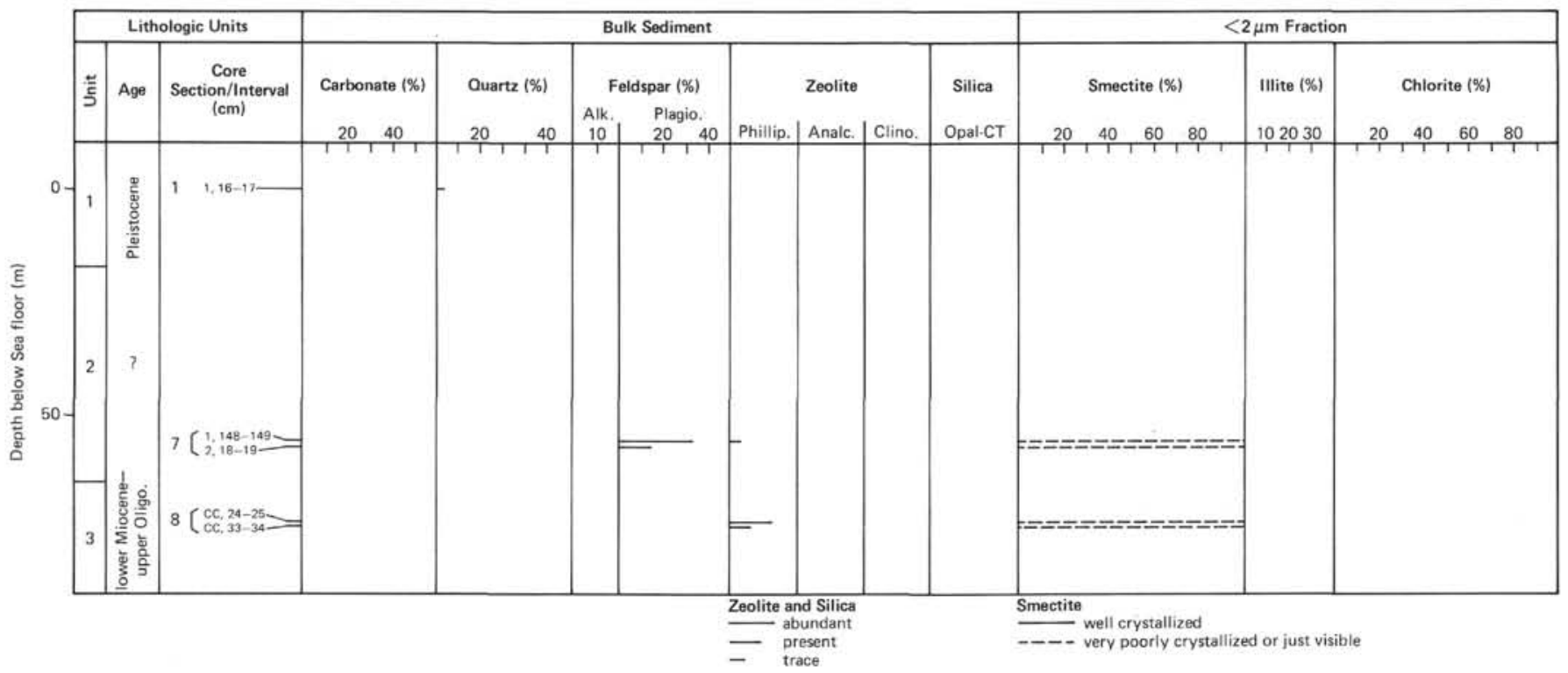

Figure 10. Mineralogical log, Hole 460A.

Table 8. X-ray diffraction analysis of bulk and fine-grained $(2 \mu \mathrm{m})$ samples from Hole 460A.

\begin{tabular}{|c|c|c|c|c|c|c|c|c|c|c|c|c|c|c|c|}
\hline \multirow[b]{3}{*}{$\begin{array}{c}\text { Sample } \\
\text { (interval in cm) }\end{array}$} & \multirow{3}{*}{$\begin{array}{l}\text { Depth below } \\
\text { Seafloor } \\
\text { (m) }\end{array}$} & \multicolumn{8}{|c|}{ Bulk Sample } & \multicolumn{6}{|c|}{$<2 \mu \mathrm{m}$ Fraction } \\
\hline & & \multirow[b]{2}{*}{$\begin{array}{c}\text { Carbonate } \\
(\%)\end{array}$} & \multirow[b]{2}{*}{$\underset{(\%)}{\text { Quartz }}$} & \multicolumn{2}{|c|}{ Feldspar } & \multirow[b]{2}{*}{$\begin{array}{l}\text { Clinoptilolite } \\
(\%)\end{array}$} & \multirow{2}{*}{$\begin{array}{l}\text { Zeolite } \\
\text { Phillipsite } \\
(\%)\end{array}$} & \multirow[b]{2}{*}{$\begin{array}{c}\text { Analcime } \\
(\%)\end{array}$} & \multirow[b]{2}{*}{$\begin{array}{c}\text { Opal-CT } \\
(\%)\end{array}$} & \multirow[b]{2}{*}{$\begin{array}{c}\text { Smectite } \\
(\%)\end{array}$} & \multirow[b]{2}{*}{$\begin{array}{l}\text { Illite } \\
(\%)\end{array}$} & \multirow[b]{2}{*}{$\begin{array}{c}\text { Chlorite } \\
(\%)\end{array}$} & \multirow[b]{2}{*}{$\begin{array}{c}\mathrm{Fe} \mathrm{Mg} \mathrm{Chlorite} \\
(\%)\end{array}$} & \multirow[b]{2}{*}{$\begin{array}{c}\text { Attapulgite } \\
(\%)\end{array}$} & \multirow[b]{2}{*}{$\begin{array}{c}\text { Serpentine } \\
(\%)\end{array}$} \\
\hline & & & & $\begin{array}{c}\text { Alkaline } \\
(\%)\end{array}$ & $\begin{array}{c}\text { Plagioclase } \\
(\%)\end{array}$ & & & & & & & & & & \\
\hline $1-1,16-17$ & 0.16 & & 1 & & 3 & & & & & & & & & & \\
\hline $7-1,148-149$ & 56.98 & & $\dot{T}$ & & 35 & & $\mathrm{~T}$ & & & 100 & & & & & \\
\hline $7 \cdot 2,18-19$ & 57.18 & & & & 16 & & & & & 100 & & & & & \\
\hline $8, \mathrm{CC}, 24-25$ & 74.24 & & & & & & A & & & 100 & & & & & \\
\hline $8, \mathrm{CC}, 33-34$ & 74.33 & & & & & & P & & & 100 & & & & & \\
\hline
\end{tabular}

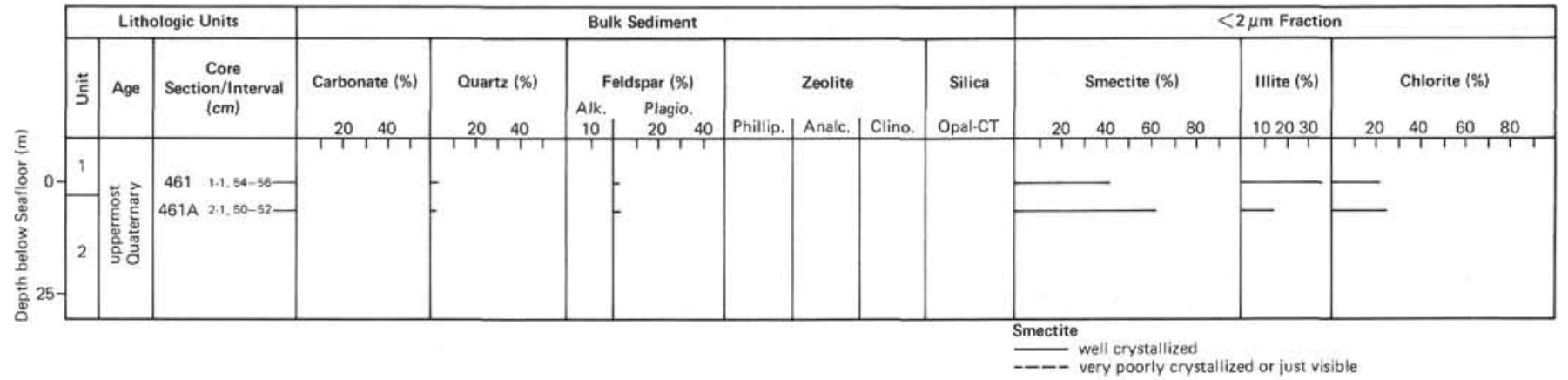

Figure 11. Mineralogical log, Holes 461 and 461A.

Table 9. X-ray diffraction analysis of bulk and fine-grained $(2 \mu \mathrm{m})$ samples from Hole 461 and $461 \mathrm{~A}$.

\begin{tabular}{|c|c|c|c|c|c|c|c|c|c|c|c|c|c|c|c|}
\hline \multirow[b]{3}{*}{$\begin{array}{c}\text { Sample } \\
\text { (interval in } \mathrm{cm} \text { ) }\end{array}$} & \multirow{3}{*}{$\begin{array}{l}\text { Depth below } \\
\text { Seafloor } \\
\text { (m) }\end{array}$} & \multicolumn{8}{|c|}{ Bulk Sample } & \multicolumn{6}{|c|}{$<2 \mu \mathrm{m}$ Fraction } \\
\hline & & \multicolumn{5}{|c|}{ Feldspar } & \multicolumn{3}{|l|}{ Zeolite } & & & & & & \\
\hline & & $\begin{array}{c}\text { Carbonate } \\
(\%)\end{array}$ & $\begin{array}{l}\text { Quartz } \\
(\%)\end{array}$ & $\begin{array}{l}\text { Alkaline } \\
(\%)\end{array}$ & $\begin{array}{c}\text { Plagioclase } \\
(\%)\end{array}$ & $\underset{(\% ; 0)}{\text { Clinoptilolite }}$ & $\begin{array}{l}\text { Phillipsite } \\
(\%)\end{array}$ & $\begin{array}{c}\text { Analcime } \\
(\%)\end{array}$ & $\begin{array}{c}\text { Opal-CT } \\
(\%)\end{array}$ & $\begin{array}{c}\text { Smectite } \\
(\%)\end{array}$ & $\begin{array}{l}\text { Illite } \\
(\%, 0)\end{array}$ & $\begin{array}{c}\text { Chlorite } \\
(\%)\end{array}$ & $\begin{array}{c}\text { Fe Mg Chlorite } \\
(\omega / 0)\end{array}$ & $\begin{array}{c}\text { Attapulgite } \\
(\%)\end{array}$ & $\begin{array}{l}\text { Serpentine } \\
(\%)\end{array}$ \\
\hline $461-1-1,54-56$ & 0.54 & & 2 & & 2 & & & & & 41 & 37 & 22 & & & \\
\hline $461 \mathrm{~A}-2-1,50-52$ & 6.50 & & 2 & & 4 & & & & & 61 & 15 & 24 & & & \\
\hline
\end{tabular}




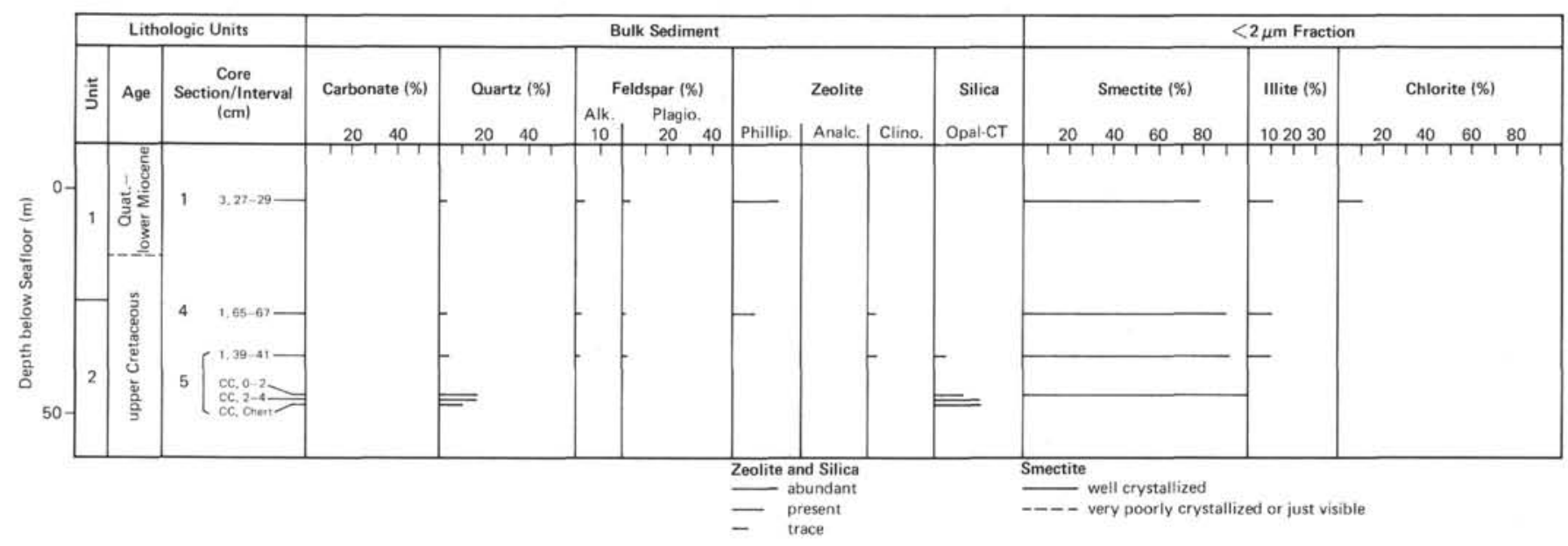

Figure 12. Mineralogical log, Hole 452A.

Table 10. X-ray diffraction analysis of bulk and fine-grained $(2 \mu \mathrm{m})$ samples from Hole $452 \mathrm{~A}$.

\begin{tabular}{|c|c|c|c|c|c|c|c|c|c|c|c|c|c|c|c|}
\hline \multirow[b]{3}{*}{$\begin{array}{c}\text { Sample } \\
\text { (interval in } \mathrm{cm} \text { ) }\end{array}$} & \multirow{3}{*}{$\begin{array}{l}\text { Depth below } \\
\text { Seafloor } \\
\text { (m) }\end{array}$} & \multicolumn{8}{|c|}{ Bulk Sample } & \multicolumn{6}{|c|}{$<2 \mu \mathrm{m}$ Fraction } \\
\hline & & \multirow[b]{2}{*}{$\begin{array}{c}\text { Carbonate } \\
(\%)\end{array}$} & \multirow[b]{2}{*}{$\begin{array}{c}\text { Quartz } \\
(\%)\end{array}$} & \multicolumn{2}{|c|}{ Feldspar } & \multirow[b]{2}{*}{$\begin{array}{c}\text { Clinoptilolite } \\
(\%)\end{array}$} & \multirow{2}{*}{$\begin{array}{l}\text { Zeolite } \\
\text { Phillipsite } \\
(\%))\end{array}$} & \multirow[b]{2}{*}{$\begin{array}{c}\text { Analcime } \\
(\%)\end{array}$} & \multirow[b]{2}{*}{$\begin{array}{c}\text { Opal-CT } \\
(\%)\end{array}$} & \multirow[b]{2}{*}{$\begin{array}{c}\text { Smectite } \\
\left(\%_{0}\right)\end{array}$} & \multirow[b]{2}{*}{$\begin{array}{l}\text { Illite } \\
(\%)\end{array}$} & \multirow[b]{2}{*}{$\begin{array}{c}\text { Chlorite } \\
(\%)\end{array}$} & \multirow[b]{2}{*}{$\begin{array}{c}\mathrm{Fe} \mathrm{Mg}_{(\%)} \text { Chlorite } \\
(\%)\end{array}$} & \multirow[b]{2}{*}{$\begin{array}{c}\text { Attapulgite } \\
(\%)\end{array}$} & \multirow[b]{2}{*}{$\begin{array}{c}\text { Serpentine } \\
(\% \%)\end{array}$} \\
\hline & & & & $\begin{array}{l}\text { Alkaline } \\
(\%))\end{array}$ & $\begin{array}{c}\text { Plagioclase } \\
(\%)\end{array}$ & & & & & & & & & & \\
\hline $1-3,27-29$ & 3.77 & & 1 & 4 & 3 & & A & & & 78 & 12 & 10 & & & \\
\hline $4-1,65-67$ & 28.15 & & 2 & i & i & $T$ & $\mathrm{p}$ & & & 90 & 10 & & & & \\
\hline $5-1,39-41$ & 37.39 & & 4 & i & i & T & & & $T$ & 90 & 10 & & & & \\
\hline $5, \mathrm{CC}, 0-2$ & 46.30 & & 16 & & & & & & $\hat{\mathrm{P}}$ & 100 & & & & & \\
\hline $5, \mathrm{CC}, 2-4$ & 46.32 & & 16 & & & & & & A & & & & & & \\
\hline 5,CC, chert & 46.31 & & 8 & & & & & & A & & & & & & \\
\hline
\end{tabular}

\section{DISCUSSION}

\section{Evolution of the Mineralogical Assemblages through Time}

Despite the peculiarities of each hole (local bathymetry, proximity to active volcanic sources, tectonics), it is possible to isolate the different stratigraphic episodes of the Tertiary. As shown in Figure 13, the sediments appear to be characterized successively by the following suites:

1) Silica, well-crystallized smectite, local clinoptilolite (Holes 459B and 452A) up to the end of the Eocent

2) Phillipsite (Holes 460 and $460 \mathrm{~A}$ ), carbonates (Holes 458 and 459B), and well-crystallized smectites (Holes 458, 459, 459A, 459B, 460), Oligocene.

3) Plagioclase and poorly crystallized clay (Hole 459B), Miocene.

4) Well-crystallized smectite (Hole 453), Pliocene.

5) Two stages can be recognized in the Pleistocene: Lower stage: plagioclase (Hole 453); plagioclase and detrital quartz (Hole 454A); detrital and autochthonous quartz, $\mathrm{Fe} \mathrm{Mg}$ chlorite (Holes 456 and 456A). Upper stage: calcite and plagioclase (Hole 454); zeolites (wairakite, clinoptilolite) (Hole 456); plagioclase, detrital quartz, well-crystallized smectite (Hole 456A).

6) Clay series with a mixture of smectite, illite, and chlorite (Holes 453, 461, and 452A), Latest Quaternary.

\section{Origin and Significance of Deposits}

Before discussing the origin and significance of the crystallized fraction it is necessary to emphasize the abundance of amorphous matter in many samples. The crystallized clay fraction is usually poorly represented.
The wide distribution of volcanic ash and glass seems generally to indicate the importance of volcanic activity in the formation of the sediments.

We have made the following generalizations from the study of the crystallized fraction.

1) The mineralogical series show little diversity, with the exception of the Pleistocene samples from Holes $453,456,456 \mathrm{~A}, 461$, and $452 \mathrm{~A}$. The crystallized fraction, when present, consists of only a few different minerals. For example, the smectites are usually the only minerals of the clay fraction, which itself is often poorly represented in the various sediments. The composition indicates the low degree of evolution of the deposits, which are composed more of "primary" components such as glasses and feldspars than of secondary material such as clay minerals and zeolites. It is probable, therefore, that only a few different sedimentary sources contributed to these deposits.

2) Crystallized silica in the form of opal-CT occurs in the Eocene samples. Various silica forms have been identified in deep ocean sediments (von Rad and Rösch, 1972; von Rad et al., 1978), especially those dating from the Upper Cretaceous and the Eocene. Their presence has been attributed to a pattern of oceanic circulation peculiar to those epochs (Ramsay, 1973); to the presence of hydrolyzing climatic conditions (Leclaire, 1974; Lancelot, 1976; Steinberg et al., 1977); to more or less complete diagenetic alteration of siliceous organisms; and sometimes to the devitrification of volcanic glass. Another explanation may be the coincidence of the radiolarite series with equatorial paleozones of high biological activity. More specifically, the occurrence of opal-CT in the Lau Basin sediments is associated with 


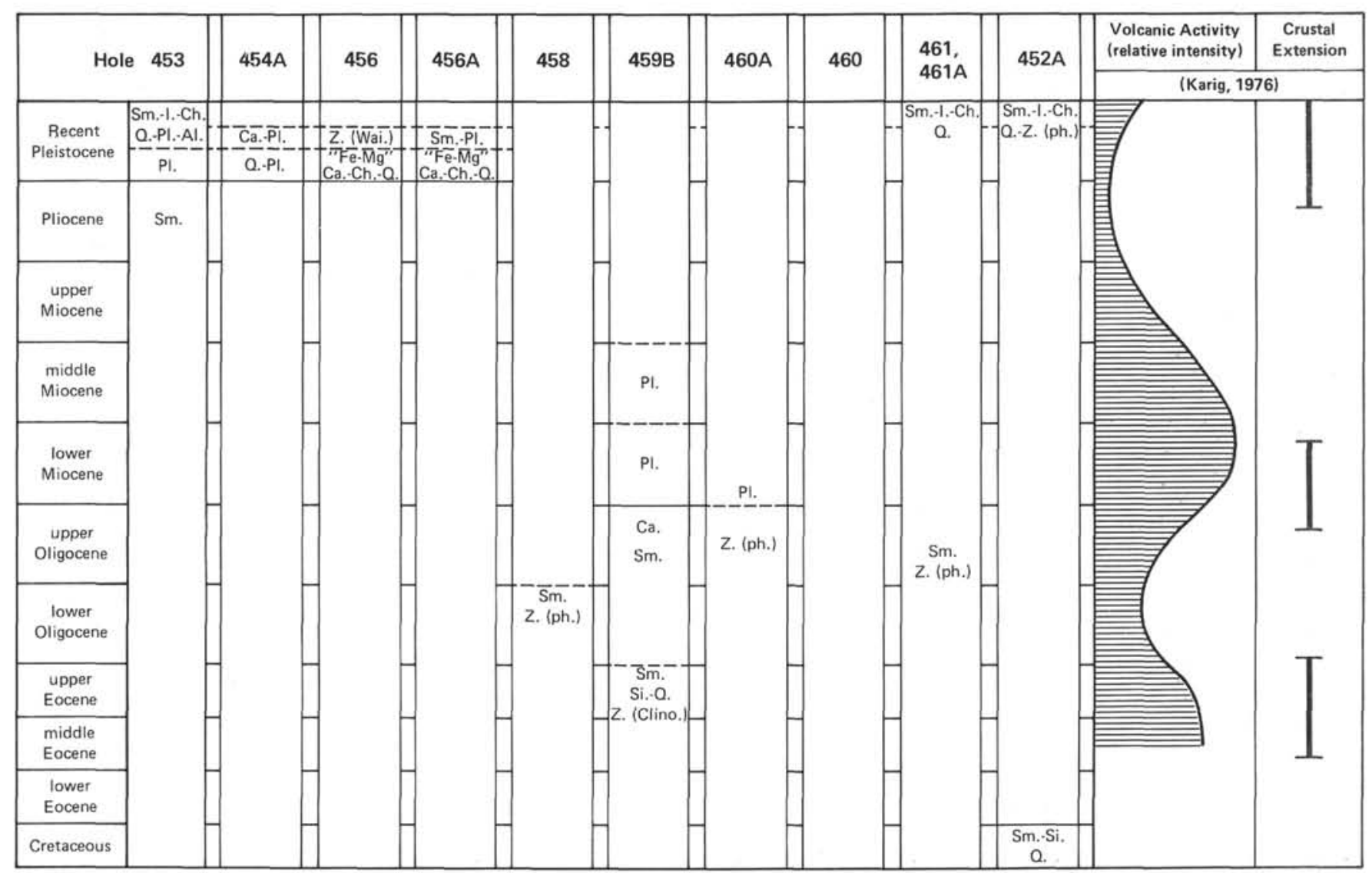

Figure 13. Mineralogical assemblages, stratigraphy, and volcanism. $(\mathrm{Sm} .=$ smectite, $\mathrm{I} .=$ illite, $\mathrm{Ch} .=$ chlorite, $\mathrm{Fe} \mathrm{Mg}=\mathrm{Fe} \mathrm{Mg}$ chlorite, $\mathrm{Q} .=$ quartz, $\mathrm{Si} .=$ silica, $\mathrm{Pl}$. = plagioclase, $\mathrm{Al}$. = K-feldspar, $\mathrm{Ca} .=$ carbonate, $\mathrm{Z}$. = zeolite, $\mathrm{Z}$. $($ wai.) $=$ zeolite wairakite, $\mathrm{Z}$. $($ clino.) $=$ zeolite clinoptilolite, $\mathrm{Z}$. (ph.) = zeolite phillipsite.)

eruptions of silica-rich lavas (Griffin et al., 1972), indicated in the present study by the presence of numerous volcanic fragments.

3) Quartz is often present, although never in quantity. This ubiquitous mineral is usually of continental origin. The crystallographic peculiarities in several samples described in (1) seem to indicate a diagenetic formation of quartz by hydrothermal action or by alteration of ultramafic rocks (Eslinger et al., 1973).

4) Plagioclase feldspars occur abundantly in many samples. Their widespread distribution and presence at various depths exclude the possibility of a diagenetic origin. We will therefore consider them primary minerals and indicative of low-grade evolution of the material.

5) $K$-feldspars are poorly represented (Hole 453). They may derive from local alteration of crystalline rocks near the hole (see Site 453 report, this volume).

6) Zeolites are always present and always in association with volcanic components. Several types were identified, and their origin has been hypothesized on the basis of the observations of many authors, particularly Kastner and Stonecipher (1976).

Phillipsites result from the alteration of the volcanic rocks with which they often occur and therefore always occur in association with smectites. In all sediments from Leg 60 containing phillipsite, smectites are also present.
Clinoptilolite/heulandite are also found associated with volcanic matter. This association seems less systematic than in the case of the phillipsites, however. Clinoptilolite formation seems linked to availability of silica, whatever its origin. Clinoptilolite crystals grown by interfilling and replacement of radiolarian tests has been described by Mélières (1979).

Wairakite, the calcic analog of analcime, is difficult to distinguish from that mineral on the basis of X-ray diffraction data alone, Natland and Hekinian (this volume) identified it in Hole 456 sediments by means of energy-dispersive X-ray fluorescence in conjunction with scanning electron microscopy. We thus infer all our Site 456 samples with analcime-like patterns also to contain wairakite. This mineral evidently forms hydrothermally at temperatures in excess of $200^{\circ} \mathrm{C}$ (e.g., Liou, 1971).

The statistical distribution of the various zeolites in the stratigraphic columns (Kastner and Stonecipher, 1976), considered on a worldwide basis, is as follows: the maximum amount of phillipsite occurs in deposits from the Oligocene to Recent. Clinoptilolites occur mainly during the early Pleistocene and before the Oligocene, and predominate during the Cretaceous. Wairakites, less abundant, occur mainly in hydrothermally modified volcaniclastic Pleistocene sediments. The distribution in Leg 60 holes is in agreement with this scheme. 
7) In the clay fraction, smectites are the best represented minerals. Their crystalline state varies, with some barely formed, as in the Miocene samples in Hole 459B, with others showing high crystallinity-for example, the Oligocene samples in Holes 458, 459B, and 460. The high frequency of smectites seems to be related to the occurrence of volcanic material such as glass and rock debris which often constitute most of the sediment. It has often been hypothesized that smectites formed in situ through underwater alteration of this volcanic matter (Yeroshev-Shak, 1964; Bonatti, 1967; Seyfried and Bischoff, 1977; Couture, 1977; Seyfried et al., 1978; Latouche et Maillet, 1979). Their frequent association with plagioclase feldspars and zeolites (particularly phillipsite) supports this hypothesis. Another origin may be partially detrital: the alteration products of basaltic outcrops. This sort of alteration could yield smectites (Latouche, 1975), formation being expedited by hot climates with highly contrasted seasons (Paquet, 1969). Because the great abundance of volcanic matter alone could explain smectite occurrence, it is difficult to isolate the effects of climate.

8) Volcanic matter may also be responsible for the $\mathrm{Fe}$ Mg chlorites in the Pleistocene sediments in Holes 456 and 456A. These minerals may represent stages in the sequence of alteration of tholeiitic basalts, as described by Siever and Kastner (in Copeland et al., 1971):

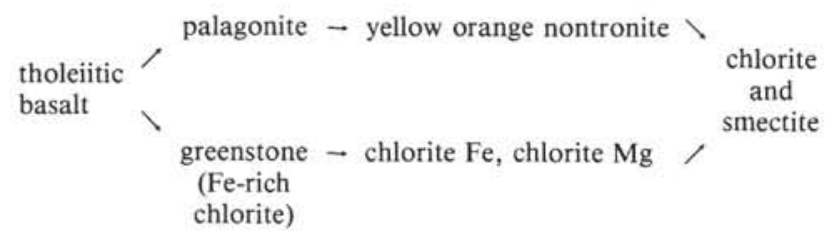

9) Attapulgites in Hole 460 have often been found in confined sedimentary basins (Millot, 1964). Several authors have observed the neoformation of attapulgites in an oceanic environment by hydrothermal action and by transformation of volcanic products (Hathaway and Sachs, 1965; Bonatti and Joensuu, 1968; Bowles et al., 1971; Hoffert et al., 1975; Lomova, 1975; Couture, 1977). Despite their relative fragility, detritial attapulgites have been found in a large variety of formations (Estéoule et al., 1970; Chamley and Millot, 1975; Chamley et al., 1979).

The very regular facies of fibers, as well as their arrangement in microbeds, argues for attapulgite formation nearly or entirely in situ. They may have had their authigenesis in the volcanic environment and been subsequently deposited in hydrodynamically calm areas.

10) An illite, chlorite, and smectite mixed association characterizes the clay phases of uppermost Quaternary deposits at all sites. In a general way, illite and chlorite are very common minerals, often accompanying detrital deposits. Their occurrence in sediments very rich in smectite may indicate a variety of sedimentary origins.

\section{Evolution of Mineralogical Series in Relation to Geodynamic Occurrences, and Volcanism}

The products of magmatic activity in active margins may act as a source for minerals in the following ways:
(1) in areas of active arcs, from volcanic ash and turbiditic deposits of volcano-detritic material; (2) in the oceanic substratum of marginal basins by alteration of the fragments of volcanic glass from the basaltic crust, and, in a complementary manner, by hydrothermal processes such as those in the active margin of the Marianas. Thus the results of this study must be viewed in terms of the calendar and as consequences of the major tectonic and magmatic events in the western Pacific. These events have been summarized in a synthetic table (see Packham et al., this volume), which complements the one presented by Karig (1975), and pays particular attention to data from Legs 5, 31, 58, 59, and 60 .

During the Eocene, Holes 459B and 460 were located on the eastern boundary of the Mariana arc ensemble, West Mariana Ridge, and Palau-Kyushu Ridge. The western part of this large area was characterized by active volcanism (Palau-Kyushu Ridge), behind which the West Philippine Basin opened to the west. The sediments in Holes 459B and 460 were situated well behind the area of volcanic activity on the Palau-Kyushu Ridge and testify to this activity by the presence of detrital volcanic deposits mixed with basic sedimentation. The latter consists of claystone and calcareous mudstone with large quantities of silica, making up silicified mudstone cherts. Without neglecting the possible action of volcanic activity, these siliceous deposits could be considered to be the regional result of the general silica crisis in the world ocean during the Eocene.

The Oligocene is characterized by a decrease of volcanic activity along the Palau-Kyushu Ridge, preceding an increase of activity along the West Mariana Ridge. The sediments contain such evolved transformation minerals as zeolites of the phillipsite type and well-crystallized smectites. Otherwise, there is a general alteration of the older series (Holes 458 and 459B).

Since the upper Oligocene ( $30 \mathrm{Ma})$, volcanic activity resumed along the West Mariana Ridge and the Parece Vela Basin opened up. This intense upper Oligocene and lower Miocene activity produced unaltered or littlealtered sediments, containing primarily plagioclase feldspars. The clays were little modified or unaltered. Volcanic activity decreased during the late Miocene. During the Pliocene-Quaternary, volcanic activity intensified along the active arc of the Marianas, and at the same time the present-day active marginal basin opened up. The sedimentary formations of Holes 454A, 456, and $456 \mathrm{~A}$ in the marginal basin are more or less evolved. In Hole 454, the crystallized fraction is represented almost exclusively by feldspars, especially the plagioclase. Clay minerals are absent. In Holes 456 and $456 \mathrm{~A}$, on the contrary, the appearance of an association of special minerals reveals a much greater alteration of primary volcanic matter: authigenic quartz, $\mathrm{Fe} \mathrm{Mg}$ chlorites, and wairakite. These minerals seem to constitute evidence for hydrothermal phenomena. The observations made on board (site chapter for 456) otherwise reveal some anomalies, tending to support this hypothesis. These include the presence of recrystallized $\mathrm{CaCO}_{3}$, pyrite, silicification, and high proportions of $\mathrm{Fe}$ and $\mathrm{Mn}$ in the sediments and of $\mathrm{Mg}$ in interstitial waters (Gieskes and Johnson, this volume). 
The latest Quaternary is characterized by a homogenization in the mineralogy of the sediments over most of the zone. The mineral series are diversified, containing quartz, K-feldspars, associations of mixed clays and smectites, illites, and chlorites. Chamley (1980) attributes the homogenization of the mineralogical series in the Shikoku Basin beginning in the early Pleistocene to a development in oceanic circulation associated with the subsidence of ridges and climatic changes. Similar processes occurring in the later Pleistocene could have been responsible for the evolution observed here.

\section{ACKNOWLEDGMENTS}

This study was supported by the Centre National de la Recherche Scientifique through Grant 3773 of the Action Thematique Programmée. The text and illustrations benefited from the reviews of $\mathrm{L}$. Montadert and $\mathrm{H}$. Chamley. We are very grateful for their reviews and valuable suggestions for improvement.

\section{REFERENCES}

Bonatti, E., 1967. Mechanisms of deep sea volcanism in the South $\mathrm{Pa}$ cific. In Abelson, P. H. (Ed.), Researches in Geochemistry (Vol. 2): New York (Wiley), 453-491.

Bonatti, E., and Joensuu, O., 1968. Palygorskite from Atlantic deep sea sediments. Am. Mineral., 53:975-983.

Bowles, F. A., Angino, E. A., Hosterman, J. W., et al., 1971. Precipitation of deep sea palygorskite and sepiolite. Earth Planet. Sci. Lett.., 11:324-332.

Brown, G., 1961. The X-Ray Identification and Crystal Structures of Clay Minerals: London (Mineralogical Society), p. 544.

Chamley, H., 1980. Clay sedimentation and paleoenvironment in the Shikoku Basin since the middle Miocene (Deep Sea Drilling Project Leg 58, North Philippine Sea). In Klein, G. de V., Kobayashi, K., et al., Init. Repts. DSDP, 58: (U.S. Govt. Printing Office), 669-682.

Chamley, H., Debrabant, P., Foulon, J., et al., 1979. Mineralogy and geochemistry of Cretaceous and Cenozoic Atlantic sediments off the Iberian Peninsula (Site 398, DSDP, Leg 47B). In Ryan, W. B. F., Sibuet, J.-C., et al., Init. Repts. DSDP, 47, Pt. 2: Washington (U.S. Govt. Printing Office), 429-450.

Chamley, H., arid Millot, G., 1975. Observations sur la répartition et la genèse des attapulgites plio-quaternaires de Méditerranée. C.R. Hebd. Seances. Acad. Sci. Ser. D, 281:1215-1218.

Copeland, R. A., Frey, F. A., and Wones, D. R., 1971. Origin of clay minerals in a Mid-Atlantic Ridge sediment. Earth Planet. Sci. Lett., 10:186-192.

Couture, R. A., 1977. Composition and origin of palygorskite and montmorillonite rich zeolite containing sediments from the Pacific Ocean. Chem. Geol., 125:113-130.

Deffeyes, K. S., 1959. Zeolites in sedimentary rocks. J. Sediment. Petrol., 29(4):602-609.

Eslinger, E. V., Mayer, L. M., Durst, T. L., et al., 1973. An X-ray technique for distinguishing between the detrital and secondary quartz in the fine-grained fraction of sedimentary rocks. $J$. Sediment. Petrol., 43(2):540-543.

Estéoule, J., Estéoule-Choux, J., Melguen, M., et al., 1970. Sur la presénce d'attapulgite dans les sédiments récents du Nord-Est du Golfe Persique. C.R. Hedb. Seances Acad. Sci. Ser. D, 271:11531156.

Fan, P. F., and Zemmels, I., 1972. X-ray mineralogy studies-Leg 12. In Laughton, A. S., Berggren, W. A., et al., Init. Repts. DSDP, 12: Washington (U.S. Govt. Printing Office), 1127-1154.

Greenwood, R., 1973. Cristobalite: Its relationship to chert formation in selected samples from the Deep Sea Drilling Project. J. Sediment. Petrol., 43(3):700-708.

Griffin, J. J., Koide, M., Höhndorf, A., et al., 1972. Sediments of the Lau Basin-rapidly accumulating volcanic deposits. Deep Sea Res., 19:139-143.

Hathaway, J. C., and Sachs, P. L., 1965. Sepiolite and clinoptilolite from the Mid-Atlantic Ridge. Am. Mineral., 50:852-867.
Hoffert, M., Lalou, C., Brichet, E., et al., 1975. Présence en Atlantique Nord de nodules de manganèse à noyaux d'attapulgite et de phillipsite authigènes. C.R. Hebd. Seances Sci. Ser. D, 281:231233.

Jones, J. B., and Segnit, E. R., 1971. The nature of opal, nomenclature and constituent phases. J. Geol. Soc. Aust., 18:57-58.

Karig, D. E., 1975. Basin genesis in the Philippine sea. In Karig, D. E., Ingle, J. C., Jr., et al., Init. Repts. DSDP, 31: Washington (U.S. Govt. Printing Office), 857-879.

Kastner, M., and Stonecipher, S. A., 1976. Zeolites in pelagic sediments of the Atlantic, Pacific and Indian Oceans. In Sand, L. B., and Mumpton, F. A. (Eds.), International Conference on Occurrence, Properties and Utilization of Natural Zeolites, Tucson, Arizona: London (Pergamon Press), pp. 199-220.

Lancelot, Y., 1976. Evolution géodynamique et histoire sédimentaire de deux grands bassins océaniques (Atlantique N-W et Pacifique) [Ph.D. dissert.]. University of Paris.

Lapaquellerie, Y., 1975. Application de la spectrométrie de fluorescence $\mathrm{X}$ en géologie marine [Ph.D. dissert.], University of Bordeaux.

Latouche, C., 1975. Les minéraux argileux des sediments actuels de l'Atlantique Nord-oriental et du Sud de la mer de Norvège. In Bailey, S. W. (Ed.), Proceedings International Clay Conference Mexico, July 16-23, pp. 45-54.

Latouche, C., and Maillet, N., 1979. X-ray mineralogy studies, Leg 48-Rockall Region (Sites 403, 404, 405, and 406). In Montadert, L., Roberts, D. G., et al., Init. Repts. DSDP, 48: Washington (U.S. Govt. Printing Office), 665-676.

Leclaire, L., 1974. Hypothèse sur l'origine des silicifications dans les grands bassins océaniques. Le rôle des climats hydrolysants. Bull. Soc. Géol. Fr., 26(2):214-224.

Liou, J. G., 1971. P-T stablilities of laumontite, wairakite, lawsonite and related minerals in the system $\mathrm{CaAl}_{2} \mathrm{Si}_{2} \mathrm{O}_{8}-\mathrm{SiO}_{2}-\mathrm{H}_{2} \mathrm{O}$. J. Petrol., 12:379-411.

Lomova, O. S., 1975. Abyssal palygorskite clays of the eastern Atlantic and their genetic relation to alkalic volcanism (from data of Legs 2 and 14 of the Glomar Challenger). Litol. Polezn. Iskop., 4:10-27. (In Russian)

Mélières, F., 1979. Mineralogy and geochemistry of selected Albian sediments from the Bay of Biscay, Deep Sea Drilling Project Leg 48, In Montadert, L., Roberts, D. G., et al., Init. Repts. DSDP, 48: Washington (U.S. Govt. Printing Office), 855-876.

Millot, G., 1974. Geologie des argiles: Paris (Masson).

Paquet, H., 1969. Evolution géochimique des minéraux argileux dans les altérations et les sols des climats méditerranéens et tropicaux à saisons contrastées. Mém. Serv. Carte Géol. Alsace Lorraine, 30.

von Rad, U., Riech, V., and Rösch, H., 1978. Silica diagenesis in continental margin sediments off Northwest Africa. In Lancelot, Y., Seibold, E., et al., Init. Repts. DSDP, 41: Washington (U.S. Govt. Printing Office), 879-906.

von Rad, U., and Rösch, M., 1972. Mineralogy and origin of clay minerals, silica and authigenic silicates in sediments. In Hayes, D. E., Pimm, A. C., et al., Init. Repts. DSDP, 14: Washington (U.S. Govt. Printing Office), 727-751.

Ramsay, A. T. S., 1973. A history of organic siliceous sediments in oceans. Syst. Assoc. Publ. 9: Spec. Pap. Paleontol., 12:199-234.

Reynolds, W. R., 1970. Mineralogy and stratigraphy of lower Tertiary clays and claystones of Alabama. J. Sediment. Petrol., 40: 829-838.

Robinson, P. T., 1966. Zeolitic diagenesis of Mio-Pliocene rocks of the silver peak ranges, Esmeralda country, Nevada. J. Sediment. Petrol., 36(4):1007-1015.

Seyfried, W. E., and Bischoff, J. L., 1977. Hydrothermal transport of heavy metals by sea water: The role of sea water/basalt ratio. Earth Planet. Sci. Lett., 34:71-77.

Seyfried, W. E., Shanks, W. C., and Dibble, W. E., 1978. Clay mineral formation in DSDP Leg 34 basalt. Earth Planet. Sci. Lett., 41:265-276.

Steinberg, M., Desprairies, A., Fogelgesang, J. F., et al., 1977. Radiolarites et sediments hypersiliceux oceaniques: une comparaison. Sedimentology, 24:547-563.

Sudo, T., and Shimoda, S., 1978. Clays and clay minerals of Japan. Developments in Sedimentology (Vol. 26): Amsterdam (Elsevier) 
Thorez, J., 1975. Phyllosilicates and Clay Minerals: Dijon (Lelotte Ed.), p. 582.

Trichet, J., 1970. Contribution à l'étude de l'altération expérimentale des verres volcaniques. Travaux du Laboratoire de Géologie de l'Ecole Normale Supérieure, Paris.

Yeroschev-Shak, V. A., 1964. Clay minerals of the Atlantic Ocean. Soviet Oceanography, Moscow/Washington, 30(2):90-106.

\section{APPENDIX}

\section{Methods}

Mineralogical studies were conducted by X-ray diffraction. The diffractometer used is a C.G.R. Theta 60 , and operating conditions were as follows: $\mathrm{CuK} \alpha$ radiation (very thin focus $0.1 \times 5 \mathrm{~mm}$ ) selected with a 40-kv, 10-ma Guinier monochromator; scanning speed: $0.5^{\circ} \theta$ p.m.

We made two types of analysis:

1. Total sediments. Dried pulverized samples of total sediments were analyzed according to the powder diffractogram method. Semi- quantitative values of quartz, calcite, and feldspars ( $\mathrm{K}$ and plagioclase) were estimated from peak height by comparison with mixed synthetic reference samples. Zeolites and crystallized silica were estimated by relative frequencies as abundant, present, or trace on the basis of the height of their characteristic reflexions.

2. Clay fraction $(<2 \mu \mathrm{m})$. Total sediments were dispersed in pure water using mechanical agitation. Samples with high carbonate content were first treated with $\mathrm{HCl} \mathrm{N} / 10$. After several (2 or 3) washings in pure water, $<2 \mu \mathrm{m}$ subfractions were separated by gravity settling. After centrifuging the $<2 \mu \mathrm{m}$ portion of the suspensions the resulting thick paste was spread across two slides with a standard laboratory spatula. The amount of clay per square centimeter transferred to the slide was always the same. The first slide was saturated with ethylene glycol before analysis. The second was scanned untreated and then heated at $550^{\circ} \mathrm{C}$ for 1 hour before a second analysis.

Identification of minerals was made according to classical methods (Brown, 1961; Thorez, 1975). Semiquantitative estimations of the different minerals were made from diagrams of the glycolated slides. Abundance was estimated relative to total clay minerals on the basis of the height of their characteristic reflexions. 

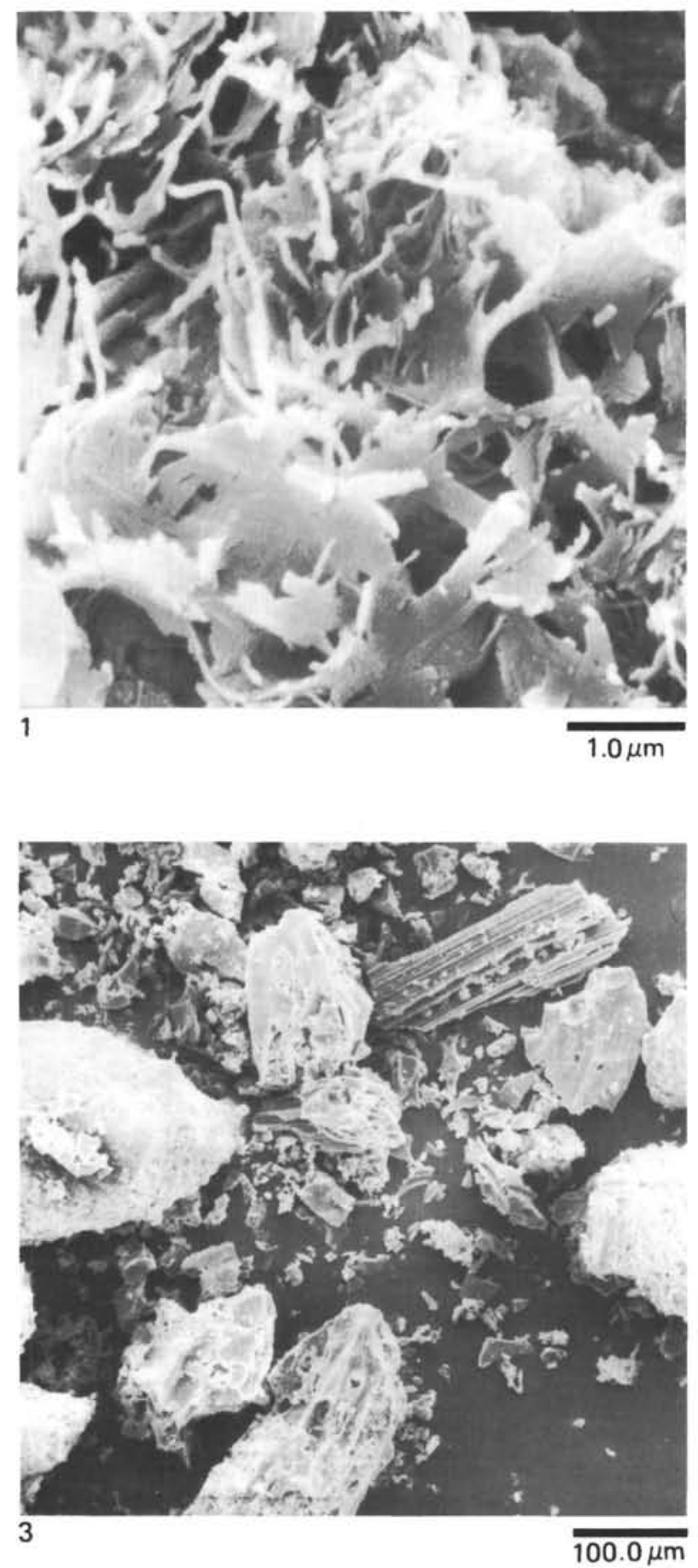

Plate 1. SEM micrographs of chlorites and other minerals in sediments recovered during Leg 60 .

Figure 1. SEM of Fe Mg chlorite and (I-M). Sample 456A-10-1, 87$90 \mathrm{~cm}$.
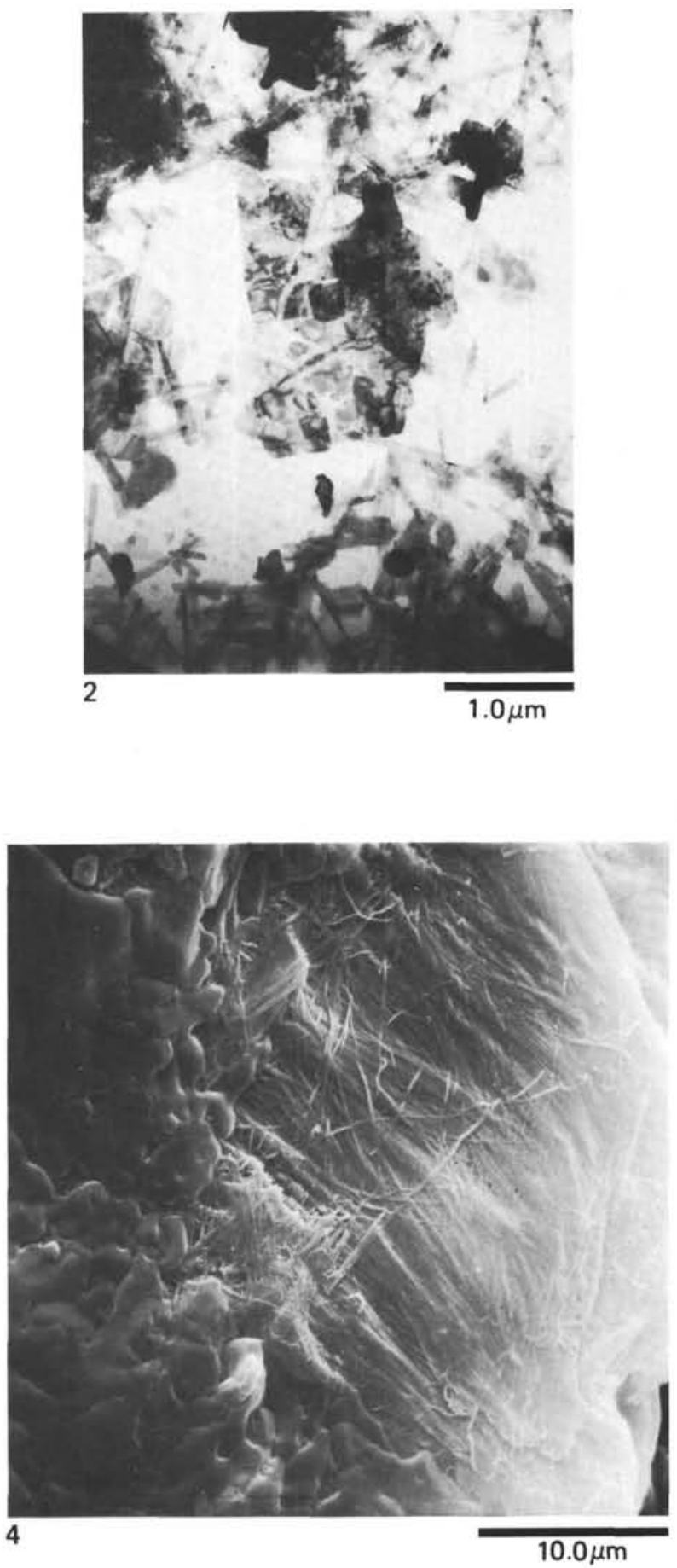

Figure 2. TEM of Fe Mg chlorite and (I-M). Sample 456A-10-1, $87-90 \mathrm{~cm}$.

Figure 3. SEM of altered bubble glass. Sample 459B-58-1, 59-60 cm. Figure 4. SEM of attapulgite. Sample 460-7-1, 103-105 cm. 